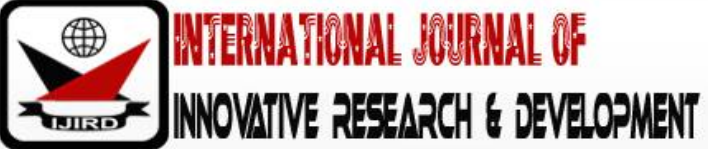

ISSN 2278 - 0211 (Online)

\section{Planning and Programing as a Factor Affecting Expanded Programme on Immunization (EPI) Vaccination in Uasin Gishu County, Kenya}

\begin{tabular}{|c|}
\hline Dr. Evans Kiprotich \\
County Director, Department of Health Services \\
Uasin Gishu County, Kenya \\
Dr. David Rop \\
Lecturer, Department of Post Graduate Studies, \\
Catholic University of Eastern Africa, Kenya \\
Sist. Lucy Wanza \\
Lecturer, Department of Post Graduate Studies, \\
Catholic University of Eastern Africa, Kenya \\
\hline
\end{tabular}

\section{Abstract:}

EPI vaccination was introduced by the world health organization (WHO) with an objective to vaccinate children throughout the world. EPI vaccination has completely eradicated disease such as polio in the world. In Kenya Kenya's immunization coverage for DTP3 has averaged between 73\% and 88\%. The dropout rate was reported at 7\% in 2009. In Uasin Gishu County immunization coverage Bacillus Calmette-Guérin (BCG), diphtheria-tetanus-pertussis (DTP), polio, measles, Hepatitis B (HepB) and yellow fever at 12 months of age declined from $91 \%$ to $88 \%$, in 2016.The study will be on planning and programing as a factor affecting expanded programme on immunization (epi) vaccination in Gasin Gishu County. The study was guided by the following objectives; to find out the influence of planning and management on EPI vaccination in Uasin Gishu County, to examine the influence of organization and coordination on EPI vaccination in Uasin Gishu County, to determine the influence of training on EPI vaccination in Uasin Gishu County and to determine the influence of communication and social mobilization on EPI vaccination in Uasin Gishu County. Cross- sectional research design was used in the study. A target population of 35 health facilities in Uasin Gishu County were targeted. A sample size of 35 health officials who are responsible for vaccination were selected to participate in the study. A census survey was carried out where one health worker in all the health centres in Uasin Gishu County was selected to participate in the study. Snowball was used to identify health workers responsible for immunization. Questionnaire with both open ended and closed ended questions was used in the study. Qualitative and quantitative data analysis was used. Quantitative analysis was used where both descriptive and inferential data analysis will be employed. In descriptive analysis mean, frequency and percentages were used. While in inferential statistics, correlation and ANOVA was used to test the relationship between variables. The study findings indicated that there was no significant relationship $(\mathrm{P}>0.05)$ between planning and planning outcomes. Correlational results indicated that in terms of organization and coordination the vaccination was fairly well organized and coordinated $(\mathrm{p} \ll 0.05)$ as opposed to epidemiological surveillance, training and communication and social mobilization. The study findings also indicated that there was a significant variation between the T-test score of $80 \%$ and the outcomes of the training evaluation. The training evaluation outcomes had a positive mean difference to indicate that the variation to implied that health workers were well trained $(\mathrm{P}<0.05)$ while the findings indicate that 27 (77.14\%) respondents said that education talks were conducted for community and social mobilization. The study concluded that planning done is not effective to enhance planning outcomes in preventing and promoting EPI vaccination at the county, organization and coordination, health facilities have not collaborated with enough stakeholders to assist them provide EPI services, that training conducted on health workers mandated to carry out EPI vaccination has been very effective and that there was non-extensive utilization of the various means of communication in to reaching people. The study recommended that; the county health department should ensure that the planning process is desirable in that, it is participatory, realistic, and flexible, so that the plan is a practical document. It also recommended that there was also need to bring on board key sectors such as community organizations and leaders, education sector, administration, private sector, church and security sectors to enhance EPI vaccination effectiveness and that county department should ensure that health facilities prioritize the use of channels that reach the largest group of people like mass media.

Keywords: EPI, vaccination, child health, social mobilization, community strategy 


\section{Introduction}

\subsection{Background}

Immunization is the process by which an individual's immune system becomes fortified against an agent known as the immunogen (Schlegel, \& Raptis, 2016). According to Turner, Magnani, \& Shuaib, 2016)Expanded program on immunization (EPI) is one of the world health organization programs, which has a goal to make vaccines available to all the children through-out the world. Koumaré, \&Dramé, (2009) noted that Expanded Program on Immunization (EPI) is estimated to prevent two-three million deaths annually from polio, diphtheria, tuberculosis, pertussis, measles, and tetanus. EPI has been delivered the immunization services to the target Group of Immunization including; all children under 1 year of age for DPT, BCG, OPV and Measles vaccination, other children who have not fully immunized, every pregnant for T.T vaccination and all other women who are of child bearing age (15- 49 years).

According to Aronson, Goodner, Yamamoto, \& Foreman, (2015), the World Health Organization (WHO) initiated the Expanded Program on Immunization (EPI) in May 1974 with the objective to vaccinate children throughout the world.Letter WHO established a standardized vaccination schedule for the original EPI vaccines: Bacillus Calmette-Guérin (BCG), diphtheria-tetanus-pertussis (DTP), oral polio, and measles. Increased knowledge of the immunologic factors of disease led to new vaccines being developed and added to the EPI's list of recommended vaccines: Hepatitis B (HepB), yellow fever in countries endemic for the disease, and Haemophilus influenzae meningitis (Hib) conjugate vaccine in countries with high burden of disease. Joh, \& Goldstein, (2013) noted that in 1999, the Global Alliance for Vaccines and Immunization (GAVI) was created with the sole purpose of improving child health in the poorest countries by extending the reach of the EPI. The creation of the GAVI has helped to renew interest and maintain the importance of immunizations in battling the world's large burden of infectious diseases (Henderson, \& Sundaresan, 2012). The goals of EPI are: to ensure full immunization of children under one year of age in every district,to globally eradicate poliomyelitis,to reduce maternal and neonatal tetanus to an incidence rate of less than one case per 1,000 births by 2005,to cut in half the number of measles-related deaths that occurred in 1999 andto extend all new vaccine and preventive health interventions to children in all districts in the world.

Immunization is the most precious gift that a Health Care Worker can give globally. According to Pickering, Baker, Freed, Gall, Grogg, Poland, \& Zimmerman, (2009), in United States of America refugees in participating sites are offered 1-3 doses of each vaccine series. Although the goal is to provide at least 2 doses of each vaccine, the vaccines administered depend on availability and logistics at each site. Before vaccination, all refugees enrolled in this program are tested for hepatitis B virus infection by hepatitis B surface antigen (HBsAg). All HBsAg results will be documented on the DS forms. Routine vaccination of U.S.-bound refugees before travel to the United States is not legally required. Olivé, Risi \& Quadros, (2007), Noted that, routine vaccinations are strongly recommended and offered overseas as part of this Vaccination Program to protect health, prevent travel delays due to disease outbreaks, and, for children, allow more rapid integration into schools after arrival in the United States. In Pakistan the National Expanded Program on Immunization aims to assure the provision of the quality immunization services that promote, protect and preserve the children of Pakistan against the vaccine preventable diseases (VPD).

Immunization in Africa is one of the main ways of preventing diseases in children and adults (Arevshatian, Clements, Lwanga, Misore, Ndumbe, Seward \& Taylor, 2007). Expanded Programme on Immunization in South Africa (EPISA) aim at preventing death and reduce suffering from infections that can be prevented by immunization of children and women (Jewkes, Dunkle, Nduna, \& Shai, 2010). Tsebe, Burnett, R. J., Hlungwani, N. P., Sibara, Venter, \& Mphahlele, 2011) noted that parents are scheduled for vaccinations in local clinics where medical staff follow a well-rehearsed routine, registering arrivals, weighing babies as part of pre-immunization checks, and vaccinating children. Health officials face the challenge of reaching the estimated 22 million children who still do not get the basic EPI vaccines. In Botswana, the Expanded Programme on Immunization is fully funded by the Government and has maintained high coverage for all recommended vaccines since 2000 (Henderson, \& Sundaresan, 2012). A survey conducted in 2007 showed that $90 \%$ of surveyed children aged 12-23 months had received all valid doses of recommended vaccines and had under-five card retention of $98 \%$. There has been a decline in cases of diphtheria, pertussis and neonatal tetanus. However, the country faces a challenge in maintaining the cold chain in its extremely hot weather. Another challenge is that vaccines such as hepatitis B have not yet been introduced in the country, even though pneumonia is a leading cause of mortality among children aged less than 1 year.

In Kenya National policy guidelines for immunization which seek to comprehensively guide health workers on vaccination priorities and acceptable practices for the overall good of all Kenyanswas developed in consultation with many partners including the World Health Organization, UNICEF, USAID-MCHIP, University of Nairobi, Kenya Medical Association, Kenya Paediatric Association and Moi University. All vaccines used in Kenya are subject to the Pharmacy \& Poisons Act Cap.244 Laws of Kenya. Ndiritu, Cowgill, Ismail, Chiphatsi, Kamau, Fegan, \& Scott, G. (2016) noted that in the last ten years, Kenya's immunization coverage for DTP3 has averaged between $73 \%$ and $88 \%$. The drop-out rate nationally was reported at 7\% in 2009. Coverage has varied, however, between counties-with some reporting DTP3 below 70\% and with DPT1-DPT3 drop-out rates above 10\%. There were also vaccine stock-outs in 2008 and the first quarter of 2009. Additionally, the division of districts and creation of new districts (from 78 to 254) has resulted in problems with denominator calculations and difficulty in ensuring fully functioning District Health Management Teams and services in many of the new districts. 


\subsection{Statement of the Problem}

EPI vaccination is supposed to reach all the targeted people irrespective of their residence and their background. All Kenyan citizens have right to access the vaccination in the country without any payment irrespective of their financial condition. The EPI vaccination is supposed to eradicate vaccine preventable disease in the country and ensure that there is zero deaths cause by those diseases. All parents with children are supposed to get the required vaccination from the public health centre without payment as per the ministry of health.

This is not actually the case the Ministry of Public Health \& Sanitation through the Division of Vaccines and Immunization aims to increase access to immunization services nationwide in order to reduce morbidity and mortality due to vaccine preventable diseases. The vaccines in the health centre are not enough for all the patients to the extent that some patients lack vaccinations especially children and women who are supposed to receive various vaccination in different stages of growth. Some patients who can afford the cost of the vaccination can seek alternative in private hospitals but those who cannot just wait for the unpredictable government vaccination. This has caused more deaths from diseases that can be prevented.In Uasin Gishu County immunization coverage for Bacillus Calmette-Guérin (BCG), diphtheria-tetanus-pertussis (DTP), polio, measles, Hepatitis B (HepB) and yellow fever at 12 months of age declined from $91 \%$ to $88 \%$, in 2016. As a result, there have been complains by the members of county assembly that the residence does not get the required vaccination like the other neighboring counties. It was believed that there are cases of corruption in the supplies of vaccines.

\subsection{Objectives of the Study}

\subsubsection{Broad Objective}

To find out how planning and programing as a factor affecting expanded programme on immunization (EPI) vaccination in Uasin Gishu County.

\subsubsection{Specific Objectives}

- To find out the influence of planning and management on EPI vaccination in Uasin Gishu County.

- To examine the influence of organization and coordination on EPI vaccination in Uasin Gishu County

- To determine the influence of training on EPI vaccination in Uasin Gishu County

- To determine the influence of communication and social mobilization on EPI vaccination in Uasin Gishu County

\subsection{Research Questions}

- How does planning and management influence EPI vaccination in Uasin Gishu County?

- What are the effects of organization and coordination on EPI vaccination in Uasin Gishu County?

- Are there effects of training on EPI vaccination in Uasin Gishu County?

- How does communication and social mobilization influence EPI vaccination in Uasin Gishu County?

\subsection{Significance of the Study}

The study will be of great significance to the ministry of health because it will be able to know the factors that affect EPI vaccination in the country.

The study also will be of great significance to the country government because it will be able to know the possible factors affecting EPI vaccination and the causes of failure to immunize the target group even with enough vaccines and resources from the ministry of health. vaccination.

The study will be of great significance to the citizens because they will be able to know the importance of

Additionally, the study will be of great significance to the to the health practitioners because due to awareness of the importance of EPI vaccination by the citizen they will not straggle encouraging patients to be vaccinated.

\subsection{Scope of the Study}

This studywas carried out in selected health centres in Uasin Gishu County. Uasin Gishu County is one of the 47 counties of Kenya, located in the former Rift Valley Province. A total of 35 health facilitiesin Uasin Gishu County was targeted. A sample size of 35 health officials who are responsible for giving Bacillus Calmette-Guérin (BCG), diphtheriatetanus-pertussis (DTP), polio, measles, Hepatitis B (HepB) and yellow fever vaccines to children under 1 year and women in child bearing age (between 15-49 years) in Uasin Gishu County. 


\subsection{Conceptual Frame Work}

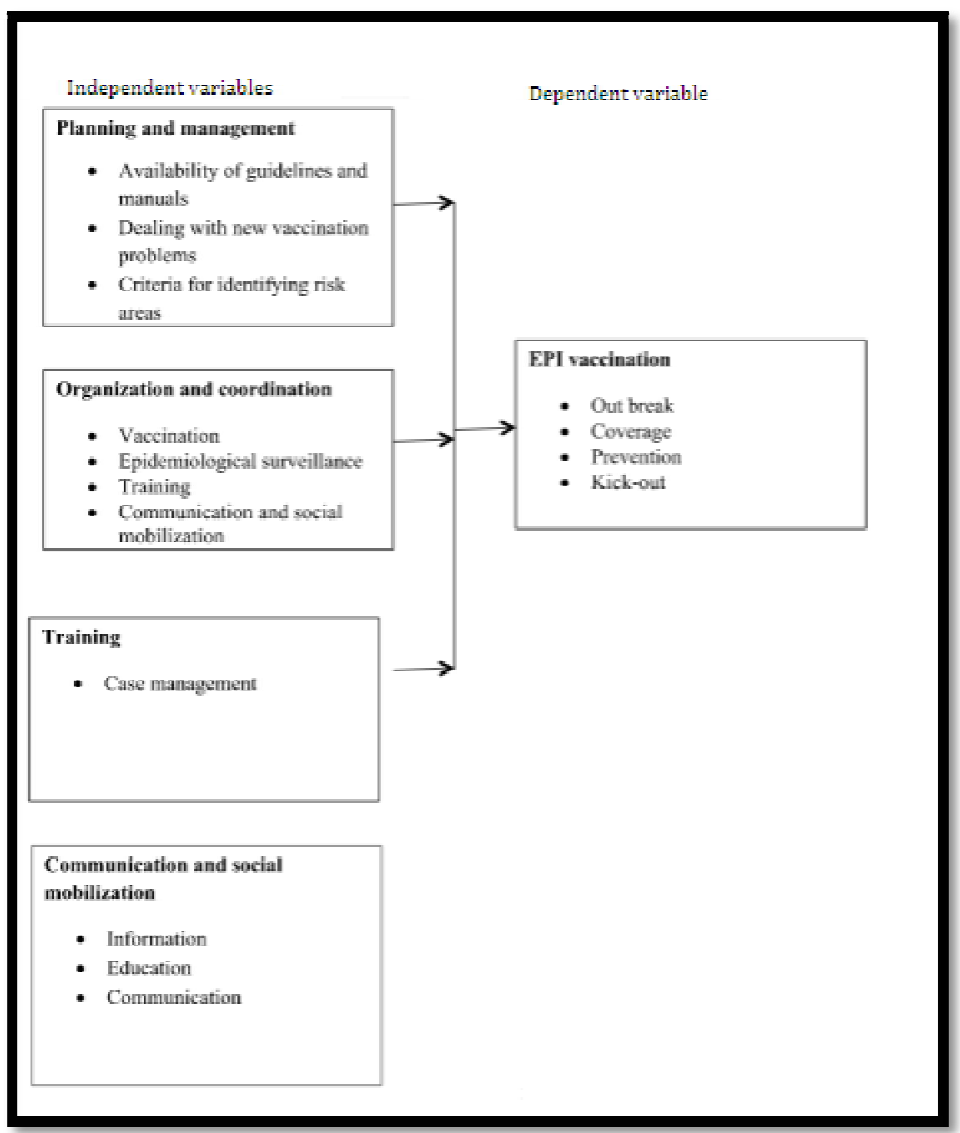

Figure 1: Conceptual Frame Work

\section{Literature Review}

\subsection{Theoretical Review}

\subsubsection{Health Belief Model}

The Health Belief Model has been applied to a broad range of health behaviors and subject populations. Three broad areas can be identified Preventive health behaviors, which include health-promoting for example diet, exercise and health-risk behaviors as well as vaccination and contraceptive practices. Sick role behaviors, which refer to compliance with recommended medical regimens, usually following professional diagnosis of illness. Clinic use, which includes physician visits for a variety of reasons.

The Health Belief Model (HBM) was developed in the early 1950s by social scientists at the U.S. Public Health Service in order to understand the failure of people to adopt disease prevention strategies or screening tests for the early detection of disease. Later uses of HBM were for patients' responses to symptoms and compliance with medical treatments. The HBM suggests that a person's belief in a personal threat of an illness or disease together with a person's belief in the effectiveness of the recommended health behavior or action will predict the likelihood the person will adopt the behavior.

The Health Belief Model has been applied to a broad range of health behaviors and subject populations. Three broad areas can be identified (Conner \& Norman, 1996): 1) Preventive health behaviors, which include health-promoting (e.g. diet, exercise) and health-risk (e.g. smoking) behaviors as well as vaccination and contraceptive practices. 2) Sick role behaviors, which refer to compliance with recommended medical regimens, usually following professional diagnosis of illness. Clinic use, which includes physician visits for a variety of reasons

Core Assumptions and Statements of the HBM is based on the understanding that a person will take a healthrelated action if that person: feels that a negative health condition can be avoided, and has a positive expectation that by taking a recommended action, he/ she will avoid a negative health condition, and believes that he/ she can successfully take a recommended

The HBM derives from psychological and behavioral theory with the foundation that the two components of health-related behavior are the desire to avoid illness, or conversely get well if already ill and the belief that a specific health action will prevent, or cure, illness. Ultimately, an individual's course of action often depends on the person's perceptions of the benefits and barriers related to health behavior. There are six constructs of the HBM. The first four constructs were developed as the original tenets of the HBM. The last two were added as research about the HBM evolved. First, perceived susceptibility that is a person's subjective perception of the risk of acquiring an illness or disease. There is wide variation in a person's feelings of personal vulnerability to an illness or disease. Secondly perceived severity that 
refers to a person's feelings on the seriousness of contracting an illness or disease or leaving the illness or disease untreated. There is wide variation in a person's feelings of severity, and often a person considers the medical consequences and social consequences when evaluating the severity.

Thirdly perceived benefits that refers to a person's perception of the effectiveness of various actions available to reduce the threat of illness or disease or to cure illness or disease. The course of action a person takes in preventing or curing illness or disease relies on consideration and evaluation of both perceived susceptibility and perceived benefit, such that the person would accept the recommended health action if it was perceived as beneficial.Additionally, perceived barriers which refer to a person's feelings on the obstacles to performing a recommended health action. There is wide variation in a person's feelings of barriers, or impediments, which lead to a cost/ benefit analysis. The person weighs the effectiveness of the actions against the perceptions that it may be expensive, dangerous for example side effects, unpleasant such as pain, time-consuming, or inconvenient.

Finally cue to action which is the stimulus needed to trigger the decision-making process to accept a recommended health action. These cues can be internal (e.g., chest pains, wheezing, etc.) or external (e.g., advice from others, illness of family member, newspaper article, etc.). Also, Self-efficacy which is the level of a person's confidence in his or her ability to successfully perform a behavior. This construct was added to the model most recently in mid-1980. Self-efficacy is a construct in many behavioral theories as it directly relates to whether a person performs the desired behavior.

Health Belief Model has limitations that limit its utility in public health. Limitations of the model include the following: First it does not account for a person's attitudes, beliefs, or other individual determinants that dictate a person's acceptance of a health behavior. Secondly it does not take into account behaviors that are habitual and thus may inform the decision-making process to accept a recommended action (e.g., smoking). Thirdly it does not take into account behaviors that are performed for non-health related reasons such as social acceptability. Also, it does not account for environmental or economic factors that may prohibit or promote the recommended action. In addition, it assumes that everyone has access to equal amounts of information on the illness or disease and finally it assumes that cues to action are widely prevalent in encouraging people to act and that "health" actions are the main goal in the decision-making process.

The HBM is more descriptive than explanatory, and does not suggest a strategy for changing health-related actions. In preventive health behaviors, early studies showed that perceived susceptibility, benefits, and barriers were consistently associated with the desired health behavior; perceived severity was less often associated with the desired health behavior. The individual constructs are useful, depending on the health outcome of interest, but for the most effective use of the model it should be integrated with other models that account for the environmental context and suggest strategies for change.

This theory deemed paramount for this study because immunization is health-related behavior are the desire to avoid illness and the belief that a specific health action will prevent, or cure, illness. The preventing a disease through immunization is a health behavior that prevent mortality and also prevent spread of the disease which is a desirable health practice. An individual's course of action often depends on the person's perceptions of the benefits and barriers related to health behavior. The belief that immunization will prevent the diseases will increase the coverage of the EPI vaccination.

\subsection{Empirical Review}

\subsubsection{How Planning Affect EPI Vaccination}

\subsubsection{How Planning and Management Programming Affect EPI Vaccination}

According to Mangrio, Alam, \& Shaikh, (2008) the annual plan of action of the Expanded Program on Immunization (EPI) is a managerial tool for programming and monitoring that facilitates the process of prioritizing activities, so as to foster efficient and timely achievement of objectives and goals. Preparinga plan of action makes it possible to implement activities consistent with defined objectives and strategies on schedule; harmonize actions and actors around a common objective; obtain and committhe necessary resources; and monitor and evaluate progress toward the defined objectives, so that adjustments can be made if necessary (DeRoeck, Bawazir, Carrasco, Kaddar, Brooks, Fitzsimmons, \& Andrus, 2016). The plan of action is a dynamic work toolthat needs to be reviewed and evaluatedon a continuous basis. Although countries have their own planning processes, the guide offers a review of some general concepts regarding planning that are common to all the countries in the Region. Prinja, Gupta, Singh, \& Kumar, (2010), noted that World Health Organization (WHO) is preparing guidelines for the formulation of multiannual plans of action that will respond to the Global Vaccine Action Plan (GVAP). The aim of the GVAP, as a new framework, is equitable access to existing vaccines for all people in all communities. According to Kim-Farley, (2012) GVAP contains five goals and six strategic objectives. The Decade of vaccines (2011-2020) Goals Strategic objectives Reach a world free of poliomyelitis. All countries commit to immunization as a priority. Individuals and communities understand the value of vaccines and demand immunization as a right and responsibility. Meet vaccination coverage targets in every region, country and community. The benefits of immunization are equitably extended to all people. Develop and introduce new and improved vaccines and technologies. Strong immunization systems are an integral part of a well-functioning health system. Exceed the Millennium Development Goal 4 target for reducing child mortality. Immunization programs have sustainable access to predictable funding, quality supply and innovative technologies. Country, regional and global research and development innovations maximize the benefits of immunization (Loevinsohn, Hong, \& Gauri, 2016).

The planning is a methodically organized process designed to achieve a defined objective and answers the questions of what must be done, how, when, by whom, and with what (Maynard, E., Kane, \&Hadler, 2009).The planning 
process is reflected in an instrument, the plan which is the means to formalize a set of actions that need to be carried out in the future in order to achieve the proposed objectives. According to Brugha, Starling, \& Walt, (2012) it is desirable for the planning process to be participatory, realistic, and flexible, so that the plan is a living document. The planning of the EPI begins with studying and assessing the health of the community, the locality, or the country, using local, national, regional and global policies as a framework. It's important to highlight the adoption of the GVAP in April 2012 by the World Health Assembly as a framework for the preparation of a situation analysis. Amin, Pierre, Ahmed, \& Haq, (2011) noted that health situation analysis include, among other things, an evaluation of the following pieces of information related to vaccine--preventable diseases (VPDs), as well as an assessment of the availability of effective vaccination services in the national network, the population's level of education and participation and the integration of the EPI with other programs, all in order to guide activities and rationalize the use of resources

According to World Health Organization (2015) general and specific morbidity, mortality and case--fatality Epidemiological surveillance of VPDs: indicators are sentinel surveillance, monitoring of events supposedly attributable to vaccination or immunization (ESAVI), Information on infrastructure, Physical resources: network of services; vaccination services available. Human resources: availability, training, motivation, Cold chain: cold chain inventory, EPI management information Coverage by age group, municipality, and special groups; survey data, Dropout rates. Consistency: simultaneous application of first, second and third doses of vaccines; oral polio vaccine (OPV)and rotavirus and pent vaccines. At-S-risk municipalities: defined with reference to socioeconomic variables such as the human development index (HDI) and unmet basic needs (UBN). The information system: coverage, integrity, timeliness, and data quality.

\subsubsection{Effects of Organization and Co-Ordination on EPI Vaccination}

Effective oversight and coordination of immunization programmes are critical to achieving national immunization goals as well as improved vaccination coverage and equity (Amin, Pierre, Ahmed, \& Haq, 2011). National coordination forums, including interagency and health sector coordination committees (ICCs and HSCCs) play a critical role in this work. National coordination forums, such as interagency coordination committees (ICCs), play a crucial role in overseeing immunization programmes. According to Hesseling, Caldwell, Cotton, Eley, Jaspan, Jennings, \& Schaaf, (2009), to be eligible for new financial or vaccine support from Gavi, countries must show that their forums have a basic functionality. They aim to ensure: strategic direction, oversight and transparency of the Expanded Programme for Immunization (EPI) and related health sector programmes; a coherent view on strategy, planning, funding and performance of the EPI programme within the context of the broader health system; and complementary activities and investments.

According to Cutts, (2008) to be eligible for new EPI vaccine or financial support, countries need to demonstrate a basic functionality of their coordination forum. In order to do this, they should adhere to the requirements outlined in our guidance document (see box below). However, Gavi recognizes that strengthening a coordination forum is an ongoing effort and can take time. We will therefore show some flexibility in approving new support provided the country clearly explains how it will address requirements that it has yet to meet. According to WHO (2015) support for strengthening coordination forums includes guidance on their membership, mandate and governance. The guidance builds on existing ICCs and HSCCs, while ensuring government ownership and leadership. Countries can also access customized, countryspecific technical assistance provided by EPI partners.

\subsubsection{Effects of Training on EPI Vaccination}

According to Ohrr, Pradhan, \& Halstead, (2015 community health workers and nurses attends Expanded Program for Immunization (EPI) Micro-Planning Training.EPI Micro Planning Training aims to equip health workers at district and health centre levels with the skills to improve planning and implementation of their EPI programs. Specifically, the training introduces the 5 key steps needed to increase coverage of vaccination programs - compiling of local immunizations data, analyzing the data then using it for planning, prioritizing and problem identification, and planning and monitoring the EPI program (Maynard, Kane, \& Hadler, 2009). Schellenberg, Menendez, Kahigwa, Aponte, Vidal, Tanner, \& Alonso, (2011) noted that one of the strengths of this training is that it is directed at the health workers who provide local level services and who understand their own challenges and areas best. It is these workers who are able to make major contributions to increasing vaccination coverage. According to Uskun, Uskun, Uysalgenc, \& Yagız, (2008) there have been many changes in the world of immunization since then, so these modules are an attempt to provide the immunization manager with up to date technical knowledge, explains how to recognize management and technical problems and take corrective action, and how to make the best use of resources.

\subsubsection{Effects of Communication and Social Mobilization on EPI Vaccination}

According to Maynard, Kane, \& Hadler, (2009) social mobilization is the process of bringing together allies to raise awareness of and demand for a particular programme, to assist in the delivery of resources and services and to strengthen community participation for sustainability and self-reliance. Allies include decision and policy-makers, opinion leaders, NGOs such as professional and religious groups, the media, the private sector, communities and individuals. Social mobilization generates dialogue, negotiation and consensus, engaging a range of players in interrelated and complementary efforts, taking into account the needs of people. Most countries have developed communication and social mobilization strategies to increase demand for immunization services as well as to encourage care givers to utilize existing services. However, community engagement and participation are usually limited to short-term successes, such as mobilization during immunization campaigns or new vaccine introductions.

Structural issues are more difficult to overcome, such as a lack of health education staff, particularly at the subnational levels. Demand creation interventions for routine immunization have been compromised due to a lack of both 
human and financial resources. There is also a lack of data to monitor the effectiveness of demand-creating activities. The existing data management systems do not incorporate indicators for communication strategies and community demand for immunization, nor is there a systematic monitoring of community engagement and participatory processes promoted by countries for demand creation. While demand creation is a crucial issue, accountability on the supply side of immunization is also important. Once communities demand vaccinations, the health system must be able to provide these needs. Moore, Bridenbaugh, Bagdi, Bridenbaugh, \& Stander, (2008) noted that is thus critical to build strong, reliable and trustworthy healthy systems in order to achieve and sustain increased immunization coverage.

Countries have adopted a mix of communication and demand creation strategies consisting of mass media messages, interpersonal communication, social mobilization and advocacy. It is generally acknowledged in the immunization community that three factors are associated with increases in coverage rates: Good physical access to services; appropriate and quality services by health staff; and acceptance and utilization of services by consumers. Maynard, Kane, \& Hadler, (2009) recommended that if limited physical access to services is the principal barrier to higher immunization coverage in a country, then the main EPI strategy should be to expand access through increased services; communication's role is limited to informing families when and where these expanded services are available. According to Brugha, Starling, \& Walt, (2012) many countries, however, are now reporting data indicating high access to services but relatively low complete coverage rates due to dropouts. Dropouts reflect a problem in one or both of the other two areas above: service barriers missed opportunities to vaccinate by health workers, poorly organized services, or consumer barriers (lack of correct information, fear of side effects, traditional belief systems.

On promoting utilization or, in other words, creating consumer demand for immunization services is appropriate strategy in the majority of developing countries where the principal challenge has been to rapidly increase immunization coverage rates. Mass media have played an important role in these demand creation strategies, and a number of countries have additionally mobilized thousands of individuals from multiple sectors of society to help deliver people to immunization services, or services to people, on the occasion of special national immunization days (World Health Organization 2009).

\subsection{Summary}

Immunization is the main way of preventing vaccine-preventable diseases $s$ in children and adults. Expanded Programme aims at preventing death and reduce suffering from infections that can be prevented by immunization of children and women. Expanded Program on Immunization (EPI) is estimated to prevent two-three million deaths annually from polio, diphtheria, tuberculosis, pertussis, measles, and tetanus and it has helped in eradication of many dangerous diseases in the world. WHO health organization (WHO) initiated the Expanded Program on Immunization (EPI) with the objective to vaccinate children throughout the world. Additionally WHO letter established a standardized vaccination schedule for the original EPI vaccines. This Increased knowledge of the immunologic factors of disease and added to the EPI's list of recommended vaccines.

EPI coverage is improved by ensuring that the cold chain is used accordingly in order to preserve the vaccines longer, communication and social mobilization, ensuring proper documentation of EPI vaccination and also proper supervision, planning and management of EPI vaccination. Health practitioners should ensure safe vaccination by ensuring vaccine and diluent vials are closely checked for damage or contamination prior to use. If damage or contamination is suspected, do not use the vaccine and contact the vaccine manufacturer for guidance.

\subsection{Research Gap}

Researchers have studied the impact of EPI vaccination on vaccine preventable diseases, how EPI is used differently in different countries to prevent disease and how EPI has helped in eradication of various diseases in the world. Also challenge facing EPI vaccination coverage in the world and how communication and socials mobilization has increased EPI coverage and the impact of cold chain in EPI immunization yet there are no studies on different factors affect EPI vaccination. Matthias, Robertson, Garrison, Newland, \& Nelson, (2007) recommended that each health facility in charge of storing vaccines or organizing vaccination sessions should have adequate functional cold chain equipment. Also, temperature in the freezer or refrigerator used to store vaccines, should be read twice daily and recorded on the temperature sheet pasted on it. Maynard, Kane, \& Hadler, (2009) noted that community mobilization helps to increase EPI vaccination coverage.

The study will be of great significance to the ministry of health because it will be able to know the factors that affect EPI vaccination in the country. The study also will be of great significance to the country government because it will be able to know the possible factors affecting EPI vaccination and the causes of failure to immunize the target group even with enough vaccines and resources from the ministry of health. In addition, the study will be of great significance to the citizens because they will be able to know the importance of vaccination, Ohrr, Tandan, Sohn, Shin, Pradhan, \& Halstead, (2015) knowing the importance of vaccination helps in increasing coverage.

\section{Research Design and Methodology}

\subsection{Introduction}

This chapter covers the study area, research design, target population, sample population, research instruments, data collection methods, data analysis and ethical issues. 


\subsection{Research Design}

The study adapted cross sectional research design. Cross sectional research design was used because of the nature of research questions. The benefit of a cross-sectional study design is that it allows researchers to compare many different variables at the same time. However, cross-sectional studies provide definite information about cause-and-effect relationships. This is because it offers a snapshot of a single moment in time; they do not consider what happens before or after the snapshot is taken.

\subsection{Target Population}

According to Mugenda (2003), target population is a population to which a researcher would like to generalize the result of the study. The target population was one official in each of the 35 health facilities in Uasin Gishu County. The study therefore targeted a total of 35 respondents which are the approximate number of health facilitiesin Uasin Gishu County. The target population is presented in Table 1

\begin{tabular}{|c|c|}
\hline Target Group & Health Center Staff \\
\hline Ainabkoi & 7 \\
\hline Moiben & 6 \\
\hline Soy & 9 \\
\hline Turbo & 13 \\
\hline Total & 35 \\
\hline
\end{tabular}

Table 1: Target Population

\subsection{Sampling Procedures and Sample Size}

\subsubsection{Sampling Procedure}

Orodho and Kombo (2002) defined sampling procedure as a process of selecting a number of individuals or objects from a population such that the selected group contains elements representative of the characteristics found in the entire group.This study used census survey where all health centres in Uasin Gishu County were selected to participate in the study. Snowball sampling was used to identify health officials who are responsible for vaccination in the health centre where the researcher used referrals from other health officials.

\subsection{Data Collection Instruments}

This refers to the tools used for collecting data and how these tools were developed and administered. The data collection instruments that was used to collect data from the selected respondents wasquestionnaires. Questionnaire was selected because of the nature of data to be collected, time available, objectives of the study and the simplicity of the instruments.

\subsubsection{Questionnaire}

Structured questionnaires were used to collect the required information from the study population. The questionnaires wereadministered to the health officials in Uasin Gishu County who are responsible for immunizing childrenunder 1 year and women on child bearing age (between 15-49 years). Using self-administered questionnaires information about EPI vaccination in Uasin Gishu County will be gathered. The questionnaire consisted of the general information which is the information of the health centre. It also consisted of staffs participating in EPI activities which include;functions in the EPI, duration position, permanent or temporary deployed in the EPI and other functions in the health facility. Finally, the questionnaire consisted of components of EPI which includes; evaluation criteria, response and comments. This method was chosen because it enabled the researcher to obtain a lot of information in a small period of time.

\subsection{Validity and Reliability of Research Instrument}

\subsubsection{Validity of Research Instruments}

According to Paton (2000) validity is quality attributed to proposition or measures of the degree to which they conform to establish knowledge or truth. An attitude scale is considered valid, for example, to the degree to which its results conform to other measures of possession of the attitude. Face and content validity of the questionnaire will be tested. Face validity is in relation to the misunderstanding or misinterpretation of the questions in the questionnaire this will be established by the researcher's presence when the respondent will be filling the questionnaire so that to give explanation in case the respondent need clarification. Content validity on the other hand refers to the capacity of the instrument to provide adequate coverage of the topic. Adequate preparation of the instruments under the guidance of the ministry of health and colleagues also will help in establishing content validity.

\subsubsection{Reliability of Research Instruments}

Reliability of research instruments is the measure of consistency of the research instrumentsif and when administered to respondent drown from different population but exhibiting similar characteristics. The reliability of research instrument in this study employed test-retest technique. This technique involved administering the same 
instrument twice to the same group of subjects. The researcher administered the questionnaire to health centres outside Uasin Gishu County which participated in the study.

\subsection{Data Collection Procedures}

A permit was obtained from the county commissioner to conduct the study. Then permits were also sought from the ministry of health and the management of the selected hospitals in Uasin Gishu County. Once the permits were granted the researcher went to the selected health centre in Uasin Gishu County. The information was gathered through on-thespot questionnaire filling for the respondents who consented to take part in the study. This ensured high return rate of the questionnaires and ruled out the problems likely to be encountered by collecting them later.

\subsection{Data Analysis Procedure}

This is organizing and ordering raw data into useful information (Mugenda 2009). Data that was collected and checked for consistency with data obtained from questionnaires and interview schedule in order to eliminate misleading data which could arise from misrepresentation of questions. Quantitative analysis was used where both descriptive and inferential data analysis was employed. In descriptive analysis mean, frequency and percentage were used. While in inferential statistics, inferential analysis was employed to determine relationship between variables.

\section{Findings, Interpratations and Discussions}

\subsection{Introduction}

This chapter sought to analyze the data collected relating to the specific objectives of the study and the dependent variable. The chapter contains the response rate, analysis of the dependent variable, analysis of specific objectives; the influence of planning and management on EPI vaccination, the influence of organization and coordination on EPI vaccination, the influence of training on EPI vaccination, and the influence of community and social mobilization on EPI vaccination.

\subsubsection{Response Rate}

The study targeted health facilities in Uasin Gishu County. The study sampled was 35 respondents and the researcher managed to collect data from all the 35 respondents. This represented a $100 \%$ response rate.

4.2. The Influence Of Planning and Management on EPI Vaccination

The study sought to analyze the descriptive of planning and management on EPI vaccinations

\subsubsection{Descriptive of Planning and Management on EPI Vaccination}

The descriptive of planning and management on EPI vaccination were presented in form of frequencies and percentages in table 1 to table 9 based on the responses of the respondents who had been selected to participate in the study.

\begin{tabular}{|c|c|c|}
\hline \multicolumn{3}{|c|}{ Do you have microprogramming that includes goals, activities, a timetable, and a budget? } \\
\hline & Frequency & Percent \\
\hline Yes & 34 & 97.14 \\
\hline NA & 1 & 2.86 \\
\hline Total & 35 & 100 \\
\hline
\end{tabular}

Table 2: Microprogramming

The findings indicated that, $34(97.14 \%)$ health centers had microprogramming that included goals, activities, a timetable and a budget while only 1 (2.86\%) did not respond.

\begin{tabular}{|c|c|c|}
\hline \multicolumn{2}{|l|}{ Does the Assigned Target Population Reflect the Reality of the Catchment Area? } \\
\hline & Frequency & Percent \\
\hline No & 7 & 20 \\
\hline Yes & 28 & 80 \\
\hline Total & 35 & 100 \\
\hline
\end{tabular}

Table 3: Reflection of Reality of the Catchment Area

The results indicated that $28(80 \%)$ of the respondents were of the opinion that the target population reflected the reality of the catchment area. Only 7 (20\%) were for the opinion that the target population did not reflect the reality of the catchment area. 


\begin{tabular}{|c|c|c|c|}
\hline \multicolumn{4}{|c|}{ Are the following guidelines or manuals available; } \\
\hline & & Frequency & Percent \\
\hline \multirow{4}{*}{$\begin{array}{c}\text { Epidemiological surveillance of vaccine-preventable } \\
\text { diseases (VPD) }\end{array}$} & NO & 5 & 14.26 \\
\hline & Yes & 26 & 74.26 \\
\hline & NA & 4 & 11.43 \\
\hline & Total & 35 & 100 \\
\hline \multirow[t]{5}{*}{ New vaccines } & & Frequency & Percent \\
\hline & No & 3 & 8.57 \\
\hline & Yes & 30 & 85.71 \\
\hline & NA & 2 & 5.71 \\
\hline & Total & 35 & 100 \\
\hline \multirow[t]{5}{*}{ EPI standards operating procedures (SOPs) } & & Frequency & Percent \\
\hline & No & 6 & 17.14 \\
\hline & Yes & 26 & 74.29 \\
\hline & NA & 3 & 8.57 \\
\hline & Total & 35 & 100 \\
\hline
\end{tabular}

Table 4: Guidelines or Manual Available

The findings indicated that $30(85.7 \%)$ of the respondents were of the opinion that they had guidelines or manuals for new vaccines, while 3(8.57\%) said that they did not have manuals or guidelines for new vaccines and an additional 2 (5.7\%) did not respond. Of the total 35 respondents 26 (74.29\% agreed that they had manuals or guidelines for Epidemiological surveillance of vaccine-preventable diseases (VPD) while 5 (14.29\%) said that they did not have manuals for Epidemiological surveillance of vaccine-preventable diseases (VPD) and 4 (11.4\%) did not respond. The findings also show that 26 (74.29\%) of the respondents were of the opinion that manuals or guidelines were available for EPI standards operating procedures (SOPs), 6 (17.14\%) respondents were of the contrary opinion that they did not have EPI standards operating procedures (SOPs) and another $3(8.57 \%)$ of the respondents did not respond.

\begin{tabular}{|c|c|c|c|}
\hline \multicolumn{4}{|c|}{ Were there anv problems with the introduction of new vaccines? } \\
\hline & & Frequency & Percent \\
\hline \multirow[t]{4}{*}{ Training } & No & 17.00 & 48.57 \\
\hline & Yes & 14.00 & 40.00 \\
\hline & NA & 4.00 & 11.43 \\
\hline & Total & 35.00 & 100.00 \\
\hline \multirow[t]{4}{*}{ Cold chain } & No & 14.00 & 40.00 \\
\hline & Yes & 18.00 & 51.43 \\
\hline & NA & 3.00 & 8.57 \\
\hline & Total & 35.00 & 100.00 \\
\hline \multirow[t]{4}{*}{ Logistics } & No & 17.00 & 48.57 \\
\hline & Yes & 14.00 & 40.00 \\
\hline & NA & 4.00 & 11.43 \\
\hline & Total & 35.00 & 100.00 \\
\hline \multirow[t]{4}{*}{ administration of the vaccine } & N0 & 18.00 & 51.43 \\
\hline & Yes & 15.00 & 42.86 \\
\hline & NA & 2.00 & 5.71 \\
\hline & Total & 35.00 & 100.00 \\
\hline \multirow[t]{4}{*}{ Information system } & No & 16.00 & 45.71 \\
\hline & Yes & 12.00 & 34.29 \\
\hline & NA & 7.00 & 20.00 \\
\hline & Total & 35.00 & 100.00 \\
\hline \multirow[t]{4}{*}{ Mobilization and mass communication } & No & 17.00 & 48.57 \\
\hline & Yes & 12.00 & 34.29 \\
\hline & NA & 6.00 & 17.14 \\
\hline & Total & 35.00 & 100.00 \\
\hline \multirow[t]{4}{*}{ other } & No & 3.00 & 8.57 \\
\hline & Yes & 4.00 & 11.43 \\
\hline & NA & 28.00 & 80.00 \\
\hline & Total & 35.00 & 100.00 \\
\hline
\end{tabular}

Table 5: Problems with the Introduction of New Vaccines 
The results indicate that 18 (51.43\%) of the respondents had a cold chain problem with the introduction of new vaccines, while $14(40 \%)$ said they had no cold chain problem with the introduction of new vaccines and the remaining 3 $(8.57 \%)$ did not respond. The findings also show that $15(42.86 \%)$ of the respondents acknowledge an administration problem with the introduction of new vaccines, while $18(51.43 \%)$ did not see an administration problem with the introduction of new vaccine, $2(5.71 \%)$ did not respond. $14(40 \%)$ of the respondents said that they had a training problem with the introduction of new vaccines, a majority $17(48.57 \%)$ were of the contrary opinion that they had no training problem with the introduction of new vaccines while $4(11.43 \%)$ did not respond. Another $14(40 \%)$ of the respondents acknowledged a logistics problem with the introduction of new vaccines while $17(48.57 \%)$ did not have a logistics problem with the introduction of new vaccines, the remaining $4(11.43 \%)$ did not respond. The findings also went on to indicate that $12(34.29 \%)$ respondents had an information system problem with the introduction of new vaccine, 16 (47.1\%) had no problem with information systems when a new vaccine was introduced and the remaining 7 (20\%) did not provide any feedback. The other results that can be generated from these findings is that $12(34.29 \%)$ had a mobilization and mass communication problem every time a new vaccine was introduced while 17 (48.57\%) respondents did not acknowledge a mobilization and mass communication problem when a new vaccine was introduced. 6 (17.14\%) respondents did not comment. $4(11.43 \%)$ respondents said that they had other problems, $3(8.57 \%)$ said they did not have any additional problems while $28(80 \%)$ did not respond or felt that the question did not apply to their case.

\begin{tabular}{|c|c|c|}
\hline \multicolumn{2}{|c|}{ Is there any record (list or map) of the communities in their health area/ catchment area? } \\
\hline & Frequency & Percent \\
\hline No & 4.00 & 11.43 \\
\hline Yes & 28.00 & 80.00 \\
\hline NA & 3.00 & 8.57 \\
\hline Total & 35.00 & 100.00 \\
\hline
\end{tabular}

Table 6: Record of Communities in the Catchment Area

The findings indicated that $28(80 \%)$ respondents said that they had a record of the communities in their health area, while only $4(11.43 \%)$ respondents had no records of communities in their catchment area and another $3(8.57 \%)$ did not respond.

\begin{tabular}{|c|c|c|c|}
\hline \multicolumn{4}{|c|}{ What criteria are used to identify risk areas? } \\
\hline \multirow{4}{*}{ Vaccination coverage } & & Frequency & Percent \\
\hline \multirow{4}{*}{ Marginalized, overcrowded or remote areas } & No & 7.00 & 20.00 \\
\cline { 2 - 4 } & Yes & 18.00 & 51.43 \\
\cline { 2 - 4 } & NA & 10.00 & 28.57 \\
\cline { 2 - 4 } & Total & 35.00 & 100.00 \\
\cline { 2 - 4 } & No & 11.00 & 31.43 \\
\cline { 2 - 4 } & Yes & 13.00 & 37.14 \\
\cline { 2 - 4 } & NA & 11.00 & 31.43 \\
\hline \multirow{4}{*}{ Traveler populations } & Total & 35.00 & 100.00 \\
\hline \multirow{4}{*}{ Reports of cases and outbreaks } & No & 13.00 & 37.14 \\
\cline { 2 - 4 } & Yes & 8.00 & 22.86 \\
\cline { 2 - 4 } & NA & 14.00 & 40.00 \\
\cline { 2 - 4 } & Total & 35.00 & 100.00 \\
\hline \multirow{4}{*}{ other } & No & 9.00 & 25.71 \\
\cline { 2 - 4 } & Yes & 16.00 & 45.71 \\
\cline { 2 - 4 } & NA & 10.00 & 28.57 \\
\cline { 2 - 4 } & Total & 35.00 & 100.00 \\
\hline & No & 3.00 & 8.57 \\
\cline { 2 - 4 } & Yes & 4.00 & 11.43 \\
\cline { 2 - 4 } & NA & 28.00 & 80.00 \\
\cline { 2 - 4 } & Total & 35.00 & 100.00 \\
\hline
\end{tabular}

Table 7: Criteria for Identifying Risk

The results of this study had $18(51.43 \%)$ respondents claiming that they used a vaccination coverage criterion to identify risk areas, $10(28.57 \%)$ did not respond while only $7(20 \%)$ did not use a vaccination coverage criterion to identify risk areas. The findings then went on to show that 16 (45.71\%) respondents used reports of cases and outbreaks as a criterion to identify risk areas, $10(28.57 \%)$ respondents did not respond while the remaining $9(25.71 \%)$ did not use reports of cases and outbreaks as a criterion for identifying risk areas. $13(37.14 \%)$ respondents were of the opinion that 
they used Marginalized, overcrowded or remote areas as a criterion for identifying risk areas, while 11 (31.43\%) did not use Marginalized, overcrowded or remote areas as a criterion for identifying risk areas. The same number of respondents did not give any feedback. The findings also indicated that 8 (22.86\%) respondents used traveler populations as a criterion for identifying risk areas while 13 (37.14\%) of the respondents did not use the criteria to identify risk factors. The other $14(40 \%)$ respondents did not provide any feedback. $4(11.43 \%)$ respondents used other criterion to identify risk factors while $3(8.57 \%)$ did not use any other criterion, 28 (80\%) did not respond.

\begin{tabular}{|c|c|c|}
\hline \multicolumn{3}{|c|}{ Is there any estimate of needs for vaccines, syringes, and supplies for vaccination in the } \\
health area/ catchment area
\end{tabular}

Table 8: Estimate Needs for Vaccines, Syringes, and Supplies for Vaccination in the Health/ Catchment Area

The results indicate that $25(71.43 \%)$ respondents had an estimate of the needs for vaccines, syringes and supplies for vaccination in the health/ catchment area, 2 (5.71\%) did not have an estimate of needs for vaccines, syringes, and supplies for vaccination in the health area/ catchment area, while 8 (22.86\%) did not respond.

\begin{tabular}{|c|c|c|}
\hline \multicolumn{3}{|c|}{$\begin{array}{c}\text { Have resources been allocated to facilitate programmed activities } \\
\text { (transportation, fuel, incidentals, paper products, etc.)? }\end{array}$} \\
\hline & Frequency & Percent \\
\hline No & 12.00 & 34.29 \\
\hline Yes & 18.00 & 51.43 \\
\hline NA & 5.00 & 14.29 \\
\hline Total & 35.00 & 100.00 \\
\hline
\end{tabular}

Table 9: Resources Allocated for Programmed Activities

The findings also indicate that 18 (51.43\%) respondents of were of the opinion that resources had been allocated to facilitate programmed activities (transportation, fuel, incidentals, paper products, etc.), $12(34.29 \%)$ respondents did not believe resources had been allocated to facilitate programmed activities (transportation, fuel, incidentals, paper products, etc.) while $5(14.29 \%)$ respondents did not respond.

\begin{tabular}{|c|c|c|}
\hline \multicolumn{3}{|c|}{$\begin{array}{c}\text { Has devolution/ decentralization had any impact (positive or negative) on } \\
\text { immunization program management? }\end{array}$} \\
\hline & Frequency & Percent \\
\hline No & 2.00 & 5.71 \\
\hline Yes & 29.00 & 82.86 \\
\hline NA & 4.00 & 11.43 \\
\hline Total & 35.00 & 100.00 \\
\hline
\end{tabular}

Table 10: Impact of Devolution on Immunization Program

The results of the findings show $29(82.86 \%)$ respondents were of the belief that devolution has had either a positive or a negative impact on immunization program management, while only $2(5.71 \%)$ respondents did not believe that devolution has had either a positive or a negative impact on immunization program management. 4 (11.43\%) gave no response.

\subsubsection{Relationship between Planning and Planning Activities Outcomes}

The study sought to determine the relationship between planning and planning outcomes. The study findings were as presented in table 10 


\begin{tabular}{|c|c|c|c|c|c|c|}
\hline \multicolumn{2}{|c|}{} & ANOVA & \\
\hline & & Sum of Squares & $\mathrm{df}$ & Mean Square & $\mathrm{F}$ & Sig. \\
\hline \multirow{2}{*}{$\begin{array}{c}\text { The availability of } \\
\text { guidelines and } \\
\text { manuals }\end{array}$} & Between Groups & .149 & 1 & .149 & 1.084 & .305 \\
\cline { 2 - 7 } & Within Groups & 4.549 & 33 & .138 & & \\
\cline { 2 - 7 } & Total & 4.698 & 34 & & & \\
\hline $\begin{array}{c}\text { Dealing with new } \\
\text { vaccination } \\
\text { problems }\end{array}$ & Between Groups & .277 & 1 & .277 & 1.321 & .259 \\
\cline { 2 - 7 } & Within Groups & 6.911 & 33 & .209 & & \\
\cline { 2 - 7 } & Total & 7.187 & 34 & & & \\
\hline $\begin{array}{c}\text { Criteria for } \\
\text { identifying risk } \\
\text { areas }\end{array}$ & Between Groups & .138 & 1 & .138 & .791 & .380 \\
\cline { 2 - 7 } & Within Groups & 5.741 & 33 & .174 & & \\
\cline { 2 - 7 } & Total & 5.879 & 34 & & & \\
\hline
\end{tabular}

Table 11: Relationship between Planning (Microprogramming) and Planning Activities Outcomes

The study findings indicated that there was no significant relationship ( $\mathrm{P}>0.05)$ between microprogramming (planning) and planning outcomes including availability of guidelines or manuals for the health facilities $(\mathrm{P}=0.305)$, problems with the introduction of new vaccines $(\mathrm{P}=2.59)$ and the criteria used in the identification of risk areas $(\mathrm{P}=0.380)$.

\begin{tabular}{|c|c|c|c|c|c|c|}
\hline \multicolumn{7}{|c|}{ Anova } \\
\hline & & Sum of Squares & Df & Mean Square & F & Sig. \\
\hline $\begin{array}{c}\text { The availability of } \\
\text { guidelines and } \\
\text { manuals }\end{array}$ & Between Groups & .924 & 2 & .462 & 3.919 & .030 \\
\cline { 2 - 7 } & Within Groups & 3.774 & 32 & .118 & & \\
\cline { 2 - 7 } & Total & 4.698 & 34 & & & \\
\hline $\begin{array}{c}\text { Dealing with new } \\
\text { vaccination problems }\end{array}$ & Between Groups & .173 & 2 & .087 & .396 & .676 \\
\cline { 2 - 8 } & Within Groups & 7.014 & 32 & .219 & & \\
\cline { 2 - 7 } & Total & 7.187 & 34 & & & \\
\hline \multirow{2}{*}{$\begin{array}{c}\text { Criteria for } \\
\text { identifying risk areas }\end{array}$} & Between Groups & .151 & 2 & .076 & .423 & .659 \\
\cline { 2 - 7 } & Within Groups & 5.728 & 32 & .179 & & \\
\cline { 2 - 7 } & Total & 5.879 & 34 & & & \\
\hline
\end{tabular}

Table 12: Relationship between Planning (Devolution) and Planning Activities Outcome

The study findings indicated that devolution (planning) and planning outcomes had varied forms of relationships where it indicated a significant relationship between manuals and guidelines $(\mathrm{p}=0.030)$, new vaccination problems $(\mathrm{P}=0.676)$ and the Criteria for identifying risk areas

The study findings imply that the form of planning including microprogramming and devolution have not had much effect on planning outcomes including enhancing availability of guidelines or manuals, the existence of problems when new vaccines were introduced and, on the criteria, used to identify risk areas. This therefore means that the planning done is not effective in a manner that would influence the planning outcomes. Despite devolution seemingly having some significant impact on planning outcomes such as ensuring the availability of guidelines or manuals the effect of devolution on other planning outcomes is not enough and hence devolution seems not to be meeting its expectations in relation to EPI vaccination.

The study findings are in contradiction with findings by Maynard, E., Kane, \&Hadler, (2009) who noted that planning is a methodically organized process designed to achieve a defined objective and answers the questions of what must be done, how, when, by whom, and with what. In our case, the planning process is not achieving the desired planning outcomes including ensuring availability of guidelines and manuals solving problems related to introduction new vaccines and assisting in formulating a robust criterion to identify risk areas.

According to Brugha, Starling, \& Walt, (2012) it is desirable for the planning process to be participatory, realistic, and flexible, so that the plan is a living document. The planning of the EPI begins with studying and assessing the health of the community, the locality, or the country, using local, national, regional and global policies as a framework. It's important to highlight the adoption of the GVAP in April 2012 by the World Health Assembly as a framework for the preparation of a situation analysis. Amin, Pierre, Ahmed, \& Haq, (2011) noted that health situation analysis include, among other things, an evaluation of the following pieces of information related to vaccine--preventable diseases (VPDs), as well 
as an assessment of the availability of effective vaccination services in the national network, the population's level of education and participation and the integration of the EPI with other programs, all in order to guide activities and rationalize the use of resources

4.3. The Influence of Organization and Coordination on EPI Vaccination

The study sought to analyze the influence of organization and coordination on EPI vaccinations

\subsubsection{Descriptives of Organization and Coordination on EPI Vaccination}

The descriptives of organization and coordinationon EPI vaccination were presented in form of frequencies and percentages in table 12 to table 15 based on the responses of the respondents who had been selected to participate in the study.

\begin{tabular}{|c|c|c|}
\hline Is there an adequate physical space (exclusive use, clean, organized, with washbasin) for vaccination activities? \\
\hline & Frequency & Percent \\
\hline No & 6.00 & 17.14 \\
\hline Yes & 26.00 & 74.29 \\
\hline NA & 3.00 & 8.57 \\
\hline Total & 35.00 & 100.00 \\
\hline
\end{tabular}

Table 13: Adequacy of Physical Space for Vaccination Activities

The results of the findings show 26 (74.29\%) respondents were of the opinion that there was adequate physical space (exclusive use, clean, organized, with washbasin) for vaccination activities, 6 (17.14\%) did not agree that there was adequate physical space (exclusive use, clean, organized, with washbasin) for vaccination activities while $3(8.57 \%)$ did not respond.

\begin{tabular}{|c|c|c|}
\hline \multicolumn{3}{|c|}{ Can the public easily identify vaccination service? } \\
\hline & Frequency & Percent \\
\hline No & 2 & 5.71 \\
\hline Yes & 30 & 85.71 \\
\hline NA & 3 & 8.571 \\
\hline Total & 35 & 100 \\
\hline
\end{tabular}

Table 14: Ease of Identification of Vaccination Services by the Public

The findings indicate that 30 (85.71\%) of the respondents were of the opinion that the public could easily identify vaccination services, while just $2(5.7 \%)$ respondents said that the public could not easily identify vaccination services. 3 $(8.57 \%)$ respondents did not give any feedback.

\begin{tabular}{|c|c|c|c|}
\hline \multicolumn{4}{|c|}{ With which sectors does the facility collaborate with? } \\
\hline \multirow{3}{*}{$\begin{array}{c}\text { Community organizations and } \\
\text { leaders }\end{array}$} & & Frequency & Percent \\
\cline { 2 - 4 } & Yes & 27 & 77.14 \\
\cline { 2 - 4 } & NA & 8 & 22.86 \\
\hline \multirow{4}{*}{ Education sector } & Total & 35 & 100.00 \\
\cline { 2 - 4 } & No & 1 & 2.86 \\
\cline { 2 - 4 } & Yes & 28 & 80.00 \\
\cline { 2 - 4 } & NA & 6 & 17.14 \\
\hline \multirow{5}{*}{ administration } & Total & 35 & 100.00 \\
\cline { 2 - 4 } & No & 1 & 2.86 \\
\cline { 2 - 4 } & Yes & 31 & 88.57 \\
\cline { 2 - 4 } & NA & 3 & 8.57 \\
\hline \multirow{5}{*}{ Private sector } & Total & 35 & 100.00 \\
\cline { 2 - 4 } & No & 9 & 25.71 \\
\cline { 2 - 4 } & Yes & 18 & 51.43 \\
\cline { 2 - 4 } & NA & 8 & 22.86 \\
\hline \multirow{5}{*}{ Church } & Total & 35.00 & 100.00 \\
\hline & No & 4.00 & 82.86 \\
\hline & Yes & 29.00 & 5.71 \\
\hline
\end{tabular}




\begin{tabular}{|c|c|c|c|} 
& Total & 35.00 & 100.00 \\
\hline \multirow{4}{*}{ Security } & No & 7.00 & 20.00 \\
\cline { 2 - 4 } & Yes & 23.00 & 65.71 \\
\cline { 2 - 4 } & NA & 5.00 & 14.29 \\
\cline { 2 - 4 } & Total & 35.00 & 100.00 \\
\hline \multirow{4}{*}{ Other } & No & 5.00 & 14.30 \\
\cline { 2 - 4 } & NA & 30.00 & 85.70 \\
\cline { 2 - 4 } & Total & 35.00 & 100.00 \\
\hline
\end{tabular}

Table 15: Collaboration with Other Sectors

The results of the findings show that $31(88.57 \%)$ respondents were of the opinion that they collaborated most with the administration while only $1(2.86 \%)$ did not agree to the existence of any collaboration with the administration. The other $3(8.57 \%)$ respondents did not give a feedback. 29 (82.86\%) respondents said that they collaborated with the church while 4 (11.43\%) did not acknowledge any collaboration with the church. 2 (5.71\%) did not give any response. On whether there was any collaboration with the Education sector 28 (80\%) said yes, they collaborated with the education sector, while 1 (2.86\%) respondents said there was no such collaboration and another $6(17.14 \%)$ did not answer. The findings also indicate that $27(77.14 \%)$ respondents said that they collaborated with community organizations and leaders while $8(22.86 \%)$ did not give a response. Also, $23(65.71 \%)$ respondents said that they collaborated with the security sector while $7(20 \%)$ respondents said they had no collaboration with the security sector. The other $5(14.29 \%)$ respondents did not give their opinion. The findings also show that 18 (51.43\%) respondents were of the opinion that they collaborated with the private sector while 9 (25.71) said no, they did not collaborate with the private sector, $8(22.86 \%)$ of the respondents did not comment on whether they had any collaboration with the private sector. Only $5(14.30 \%)$ respondents said that they had no other collaboration with sectors not mentioned in the questionnaire and another 30 $(85.70 \%)$ did not comment on the same.

\begin{tabular}{|c|c|c|c|}
\hline \multicolumn{2}{|c|}{ What types of activities are supported by other stakeholders } \\
\hline \multirow{4}{*}{ Vaccination } & & Frequency & Percent \\
\hline \multirow{4}{*}{ Epidemiological surveillance } & No & 14.00 & 40.00 \\
\cline { 2 - 4 } & Yes & 14.00 & 40.00 \\
\cline { 2 - 4 } & NA & 7.00 & 20.00 \\
\cline { 2 - 4 } & Total & 35.00 & 100.00 \\
\cline { 2 - 4 } & No & 6.00 & 17.14 \\
\cline { 2 - 4 } & Yes & 20.00 & 57.14 \\
\cline { 2 - 4 } & NA & 9.00 & 25.71 \\
\hline \multirow{4}{*}{ Training } & Total & 35.00 & 100.00 \\
\cline { 2 - 4 } & No & 7.00 & 20.00 \\
\cline { 2 - 4 } & Yes & 20.00 & 57.14 \\
\cline { 2 - 4 } & NA & 8.00 & 22.86 \\
\hline Communication and social mobilization & Total & 35.00 & 100.00 \\
\cline { 2 - 4 } & No & 2.00 & 5.71 \\
\cline { 2 - 4 } & Yes & 28.00 & 80.00 \\
\cline { 2 - 4 } & NA & 5.00 & 14.29 \\
\cline { 2 - 4 } & Total & 35.00 & 100.00 \\
\hline \multirow{4}{*}{ Others } & Yes & 1.00 & 2.86 \\
\cline { 2 - 4 } & NA & 34.00 & 97.14 \\
\cline { 2 - 4 } & Total & 35.00 & 100.00 \\
\hline
\end{tabular}

Table 16: Activities Supported by Other Stakeholders

The findings also show that $28(80 \%)$ of the respondents agree that the other sectors supported communication and social mobilization, while $2(5.71 \%)$ respondents said the other sectors they collaborated with provided no support for community and social mobilization, 9 (25.71\%) respondents did not provide feedback. Also, 20 (57.14\%) respondents were of the opinion that sectors they collaborated with provided support for epidemiological surveillance, while 6 (17.14\%) respondents did not acknowledge any support on epidemiological surveillance provided by the sectors they collaborated with. The other $9(25.71 \%)$ respondents did not respond. The findings went on to show that $20(57.14 \%)$ respondents acknowledged that the sectors they collaborated with provide training support while 7 (20\%) respondents said that no support on training was provided, and another 8 (22.86\%) respondents did not respond. On whether support on vaccination was provided, 14 (40\%) respondents said yes while an equal number said that no support on vaccination 
was provided. 7 (20\%) respondents did not comment on the issue of training. $1(2.86 \%)$ respondent said the sectors provided support on other activities not mentioned in the questionnaire while 34 (97.14\%) did not give a response.

\subsubsection{Correlational Results of Organization and Coordination}

The study sought to determine the correlation between organization and coordination. The study findings were as presented in table 16

\begin{tabular}{|c|c|c|c|c|c|c|c|}
\hline & & $\begin{array}{c}\text { Community } \\
\text { organizations and } \\
\text { leaders }\end{array}$ & $\begin{array}{l}\text { Educatio } \\
\text { n sector }\end{array}$ & Administration & $\begin{array}{c}\text { private } \\
\text { sector }\end{array}$ & Church & Security \\
\hline \multirow[t]{3}{*}{ vaccination } & Pearson & $.600^{* *}$ & $.450^{* *}$ & 0.16 & -0.175 & -0.223 & -0.026 \\
\hline & Sig. (2-tailed) & 0.000 & 0.007 & 0.357 & 0.313 & 0.197 & 0.881 \\
\hline & $\mathrm{N}$ & 35 & 35 & 35 & 35 & 35 & 35 \\
\hline \multirow{3}{*}{$\begin{array}{l}\text { Epidemiological } \\
\text { surveillance }\end{array}$} & Pearson & 0.138 & 0.163 & 0.242 & -0.121 & 0.126 & 0.315 \\
\hline & Sig. (2-tailed) & 0.43 & 0.349 & 0.162 & 0.489 & 0.472 & 0.065 \\
\hline & $\mathrm{N}$ & 35 & 35 & 35 & 35 & 35 & 35 \\
\hline \multirow[t]{3}{*}{ Training } & Pearson & 0.08 & -0.015 & -0.007 & 0.127 & 0.006 & 0.229 \\
\hline & Sig. (2-tailed) & 0.647 & 0.933 & 0.966 & 0.466 & 0.972 & 0.185 \\
\hline & $\mathrm{N}$ & 35 & 35 & 35 & 35 & 35 & 35 \\
\hline \multirow{3}{*}{$\begin{array}{l}\text { Communication } \\
\text { and social } \\
\text { mobilization }\end{array}$} & Pearson & 0.049 & 0.241 & $.357^{*}$ & -0.272 & -0.29 & 0.131 \\
\hline & Sig. (2-tailed) & 0.781 & 0.162 & 0.035 & 0.113 & 0.091 & 0.454 \\
\hline & $\mathrm{N}$ & 35 & 35 & 35 & 35 & 35 & 35 \\
\hline
\end{tabular}

Table 17: Correlational Results of Organization and Coordination

**. Correlation Is Significant at the 0.01 Level (2-Tailed)

*. Correlation Is Significant at the 0.05 Level (2-Tailed)

Correlational results indicated that in terms of organization and coordination the vaccination was fairly well organized and coordinated as opposed to epidemiological surveillance, training and communication and social mobilization. The results indicated that there was a relationship between vaccination and community organizational and leaders $(p=0.000)$, there was a relationship between vaccination and private sector $(p=0.007)$. The study findings also indicated that there was a relationship between communication and social mobilization and administration (0.357).

These results are interpreted to mean that organization and coordination in preventing and promoting EPI evaluation is very weak. Despite vaccination appearing to be relatively planned and coordinated many more actors including private sector, church, administration and security sector were not involved in vaccination. All the other EPI activities were left to the health sector including training, epidemiological surveillance and communication and social mobilization which was partially supported by the administration.

These study findings negate to what is recommended by Amin, Pierre, Ahmed, \& Haq, (2011) who noted that effective oversight and coordination of immunization programmes are critical to achieving national immunization goals as well as improved vaccination coverage and equity. in our study, key stakeholders including community organizations and leaders, education sector, administration, private sector, church and security sector are seemingly not supporting activities related to EPI vaccination and in few cases where they do the support is weak and insufficient.

\subsection{Influence of Training on EPI Vaccination}

The study sought to analyze the influence of training on EPI vaccinations

\subsubsection{Descriptives of Training on EPI Vaccination}

The descriptives of training on EPI vaccination were presented in form of frequencies and percentages in table 16 to table 19 based on the responses of the respondents who had been selected to participate in the study.

\begin{tabular}{|c|c|c|}
\hline \multicolumn{2}{|c|}{ When was the last time that you received training in immunization programme activities? } \\
\hline & Frequency & Percent \\
\hline No & 10.00 & 28.57 \\
\hline Yes & 3.00 & 8.57 \\
\hline NA & 22.00 & 62.86 \\
\hline Total & 35.00 & 100.00 \\
\hline
\end{tabular}

Table 18: Training on Immunization Program Activities

The findings suggest that many majorities of the responses 10 () n did not receive 


\begin{tabular}{|c|c|c|c|}
\hline \multicolumn{4}{|c|}{ What topics were covered? } \\
\hline & & Frequency & Percent \\
\hline \multirow[t]{4}{*}{ Planning and programming } & No & 9.00 & 25.71 \\
\hline & Yes & 19.00 & 54.29 \\
\hline & NA & 7.00 & 20.00 \\
\hline & Total & 35.00 & 100.00 \\
\hline \multirow[t]{4}{*}{ cold chain } & No & 14.00 & 40.00 \\
\hline & Yes & 16.00 & 45.71 \\
\hline & NA & 5.00 & 14.29 \\
\hline & Total & 35.00 & 100.00 \\
\hline \multirow[t]{4}{*}{ vaccine safety } & No & 14.00 & 40.00 \\
\hline & Yes & 16.00 & 45.71 \\
\hline & NA & 5.00 & 14.29 \\
\hline & Total & 35.00 & 100.00 \\
\hline \multirow[t]{4}{*}{ Information systems } & No & 13.00 & 37.14 \\
\hline & Yes & 16.00 & 45.71 \\
\hline & NA & 6.00 & 17.14 \\
\hline & Total & 35.00 & 100.00 \\
\hline \multirow[t]{4}{*}{ Information and management of AEFI } & No & 13.00 & 37.14 \\
\hline & Yes & 16.00 & 45.71 \\
\hline & NA & 6.00 & 17.14 \\
\hline & Total & 35.00 & 100.00 \\
\hline \multirow[t]{4}{*}{ Epidemiological surveillance } & No & 15.00 & 42.86 \\
\hline & Yes & 13.00 & 37.14 \\
\hline & NA & 7.00 & 20.00 \\
\hline & Total & 35.00 & 100.00 \\
\hline \multirow[t]{4}{*}{ Coverage monitoring } & No & 11.00 & 31.43 \\
\hline & Yes & 18.00 & 51.43 \\
\hline & NA & 6.00 & 17.14 \\
\hline & Total & 35.00 & 100.00 \\
\hline \multirow[t]{4}{*}{ Introduction of new vaccines } & No & 10.00 & 28.57 \\
\hline & Yes & 12.00 & 34.29 \\
\hline & NA & 13.00 & 37.14 \\
\hline & Total & 35.00 & 100.00 \\
\hline \multirow[t]{4}{*}{ Others } & No & 2.00 & 5.71 \\
\hline & Yes & 4.00 & 11.43 \\
\hline & NA & 29.00 & 82.86 \\
\hline & Total & 35.00 & 100.00 \\
\hline
\end{tabular}

Table 19: Topics Covered on Immunization Programme Activities

The results show that 19 (54.29\%) respondents received training on planning and programming while 9 (25.71\%) respondents have not undergone training on planning and programming and 7 (20\%) respondents did not give any feedback. On whether they covered a topic on coverage monitoring 18 (51.43\%) respondents said yes, they covered the topic during training while $11(31.43 \%)$ had not covered the topic, and $6(17.14 \%)$ felt that either the topic did not apply to them or failed to give any response for some other reason. The results also indicated that $16(45.71 \%)$ respondents had received training on vaccine safety, while 14 (40\%) respondents said they had not covered the topic during training while $5(14.29 \%)$ respondents did not give a response. Another 16 (45.71\%) respondents said they had covered the cold chain topic in training while $14(40 \%)$ did not cover the topic in training and $5(14.29 \%)$ did not make a comment. 16 (45.71\%) of the respondents said they covered a topic on information system in training while 13 (37.14\%) said they had not come across the topic in training and $6(17.14 \%)$ did not give a response. the study also shows that 16 (45.71\%) of the respondents said they covered a topic on Information and management of AEFI in training while 13 (37.14\%) said they had not come across the topic in training and $6(17.14 \%)$ did not give a response. on whether the respondents covered a topic on Epidemiological surveillance training, $13(37.14 \%)$ said yes, while $15(42.86 \%)$ said they had not covered the topic in training and $7(20 \%)$ respondents did not provide feedback. The findings also show that 12 $(34.29 \%)$ respondents had received training on the introduction of new vaccines while $10(28.57 \%)$ respondents replied 
that they had not covered the topic on introduction of new vaccines in training and a significant number $(13=37.14 \%)$ did not make any comment on the same. Also, $4(11.43 \%)$ respondents said they had covered other topics in training while 2 $(5.71 \%)$ said no, they had not covered any other topics during training and 29 (82.86\%) did not answer.

\begin{tabular}{|c|c|c|}
\hline \multicolumn{3}{|c|}{ Evaluate whether the interviewee is familiar with the EPI vaccination schedule } \\
\hline & Frequency & Percent \\
\hline No & 2 & 5.71 \\
\hline Yes & 31 & 88.57 \\
\hline NA & 2 & 5.71 \\
\hline Total & 35 & 100.00 \\
\hline
\end{tabular}

Table 20: Familiarity with the EPI Vaccination Schedule

According to the findings, 31 (88.57\%) respondents were familiar with the EPI vaccination schedule while only 2 $(5.71 \%)$ were not familiar with the EPI vaccination schedule. Another $2(5.71 \%)$ respondents failed to respond.

\begin{tabular}{|c|c|c|}
\hline \multicolumn{3}{|c|}{ Evaluate whether the interviewee is familiar with the concept of drop-out or default rate. } \\
\hline & Frequency & Percent \\
\hline No & 2 & 5.71 \\
\hline Yes & 31 & 88.57 \\
\hline NA & 2 & 5.71 \\
\hline Total & 35 & 100.00 \\
\hline
\end{tabular}

Table 21: Familiarity with the Concept of Drop-Out or Default Rate

The findings indicate that 31 (88.57\%) respondents were familiar with the concept of drop-out or default rate. Only $2(5.71 \%)$ respondents were not familiar with the concept of drop-out or default rate. Another 2 did not respond.

\begin{tabular}{|c|c|c|c|}
\hline \multicolumn{4}{|c|}{ Evaluate whether the interview ee knows how to manage the following cases: } \\
\hline Which vaccine would you administer to a 7- & & Frequency & Percent \\
\cline { 2 - 4 } $\begin{array}{c}\text { month old who has had one dose of BCG, one of } \\
\text { PENTA, and one of OPV, and the doses of }\end{array}$ & No & 2 & 5.71 \\
\cline { 2 - 4 } $\begin{array}{c}\text { PENTA and OPV were administered five weeks } \\
\text { ago? }\end{array}$ & Yes & 29 & 82.86 \\
\cline { 2 - 4 } & NA & 4 & 11.43 \\
\cline { 2 - 4 } & Total & 35 & 100.00 \\
\hline $\begin{array}{c}\text { Which vaccines would you administer to a 15- } \\
\text { month old child who has never been } \\
\text { vaccinated? }\end{array}$ & No & 2 & 5.71 \\
\cline { 2 - 4 } \begin{tabular}{c} 
Yes \\
\cline { 2 - 4 }
\end{tabular} & NA & 29 & 11.43 \\
\cline { 2 - 4 } & Total & 35 & 100 \\
\hline
\end{tabular}

Table 22: Case Management

The results show that 29 (82.86\%) respondents knew which vaccine to administer to a 7-month old who has had one dose of BCG, one of PENTA, and one of OPV, and the doses of PENTA and OPV were administered five weeks ago, While 2 (5.71\%) did not know how to manage such a case and another 4 (11.43\%) did not give a response. Another $29(82.86 \%)$ respondents knew which vaccines to administer to a 15-month old child who has never been vaccinated, while 2 (5.71\%) did not know which vaccine to administer in such a case while 4 (11.43\%) respondents did not comment.

\subsubsection{Relationship between Training and Training Evaluation Results}

The study sought to determine the relationship between training and training evaluation results. The study findings were as presented in table 16 


\begin{tabular}{|c|c|c|c|c|c|c|}
\hline \multicolumn{7}{|c|}{ One-Sample Test } \\
\hline & \multirow[b]{3}{*}{$\mathrm{t}$} & & & est Value $=.8$ & & \\
\hline & & \multirow[b]{2}{*}{ Df } & \multirow[b]{2}{*}{ Sig. (2-tailed) } & \multirow[b]{2}{*}{ Mean Difference } & \multicolumn{2}{|c|}{ 95\% Confidence Interval of the } \\
\hline & & & & & Lower & Upper \\
\hline Evaluate whether the & 3.305 & 32 & .002 & .13939 & .0535 & .2253 \\
\hline Evaluate whether the & 3.305 & 32 & .002 & .13939 & .0535 & .2253 \\
\hline Which vaccine would you & 3.021 & 30 & .005 & .13548 & .0439 & .2271 \\
\hline Which vaccines would you & 3.021 & 30 & .005 & .13548 & .0439 & .2271 \\
\hline
\end{tabular}

Table 23: Relationship between Training and Training Evaluation Results

The study findings indicated that there was a significant variation between the T-test score of $80 \%$ and the outcomes of the training evaluation. The training evaluation outcomes had a positive mean difference to indicate that the variation to implied that health workers were well trained $(\mathrm{P}<0.05)$ on familiarity with the EPI vaccination schedule $(\mathrm{p}=$ 0.002), on familiarity with the concept of drop-out or default rate $(P=0.002)$, on the vaccine to administer to a 7-month old who has had one dose of BCG, one of PENTA, and one of OPV, and the doses of PENTA and OPV were administered five weeks ago ( $p=0.005$ ), and on the vaccines to administer to a 15-month old child who has never been vaccinated.

The results imply that training conducted to healthcare workers to assist on EPI vaccination is effective on all matters relating to EPI vaccination especially those relating to the EPI vaccination schedule, the concept of drop-out or default rate, the vaccine administered to a 7-month old who has had one dose of BCG, one of PENTA, and one of OPV, and the doses of PENTA and OPV were administered five weeks ago, and the vaccines administered to a 15-month old child who has never been vaccinated.

These findings are in agreement with Ohrr, Pradhan, \& Halstead, (2015 community health workers and nurses attends Expanded Program for Immunization (EPI) Micro-Planning Training. EPI Micro Planning Training aims to equip health workers at district and health centre levels with the skills to improve planning and implementation of their EPI programs. Specifically, the training introduces the 5 key steps needed to increase coverage of vaccination programs compiling of local immunizations data, analyzing the data then using it for planning, prioritizing and problem identification, and planning and monitoring the EPI program. Our findings indicate that health workers in the health facilities in the county has attended training on EPI vaccination and are well equipped on the various skills required to successful administer vaccines.

The study also agrees with Schellenberg, Menendez, Kahigwa, Aponte, Vidal, Tanner, \& Alonso, (2011) who noted that one of the strengths of this training is that it is directed at the health workers who provide local level services and who understand their own challenges and areas best. It is these workers who are able to make major contributions to increasing vaccination coverage. According to Uskun, Uskun, Uysalgenc, \& Yagız, (2008) there have been many changes in the world of immunization since then, so these modules are an attempt to provide the immunization manager with up to date technical knowledge, explains how to recognize management and technical problems and take corrective action, and how to make the best use of resources. According to our study, health workers have benefited from the trainings and can specifically respond to the vaccination needs of the areas they serve.

\subsection{Communication and Social Mobilization}

The study sought to analyze the influence of communication and social mobilization on EPI vaccinations.

\begin{tabular}{|c|c|c|c|}
\hline \multicolumn{2}{|c|}{ What types of information, education, and communication activities are carried out? } \\
\hline & & Frequency & Percent \\
\hline Education talks & No & 3 & 8.57 \\
\hline & Yes & 27 & 77.14 \\
\hline & NA & 5 & 14.29 \\
\hline & Total & 35 & 100.00 \\
\hline & No & 17 & 48.57 \\
\hline Publicly using a loud speaker & Yes & 11 & 31.43 \\
\hline & NA & 7 & 20.00 \\
\hline Radio/ television interviews or announcements & Total & 35 & 100.00 \\
\hline & No & 17 & 48.57 \\
\hline & Yes & 10 & 28.57 \\
\hline & NA & 8 & 22.86 \\
\hline & Total & 35 & 100.00 \\
\hline Posters, signs & No & 4 & 11.43 \\
\hline & Yes & 26 & 74.29 \\
\hline
\end{tabular}




\begin{tabular}{|c|c|c|c|} 
& NA & 5 & 14.29 \\
\hline & Total & 35 & 100.00 \\
\hline & No & 7 & 20.00 \\
\hline Health fairs & Yes & 18 & 51.43 \\
\hline & NA & 10 & 28.57 \\
\hline & Total & 35 & 100.00 \\
\hline School-based activities & No & 7 & 20.00 \\
\hline & Yes & 22 & 62.86 \\
\hline & NA & 6 & 17.14 \\
\hline & Total & 35 & 100.00 \\
\hline Other & No & 3 & 8.57 \\
\hline & Yes & 7 & 20.00 \\
\hline & NA & 24 & 68.57 \\
\hline & 3 & 1 & 2.86 \\
\hline & Total & 35 & 100.00 \\
\hline
\end{tabular}

Table 24: Communication and Social Mobilization

The findings indicate that 27 (77.14\%) respondents said that education talks were conducted for community and social mobilization while 3 (8.57\%) of the respondents said no education talks were conducted and the other $45(14.29 \%)$ did not give their opinion. The results also show that $26(74.29 \%)$ respondents used posters and signs for community and social mobilization while only 4 (11.43\%) did not carry out mobilization using posters or signs. The other 5 (14.29\%) did not respond. According to the results $22(62.86 \%)$ respondents used school-based activities to mobilize the community, while 7 (20\%) did not use school-based activities and $6(17.14 \%)$ did not give a response. also 18 (51.43\%) respondents used health fairs for community and social mobilization while 7 (20\%) said they did not use health fairs to mobilize the communities, and another 10 (28.57\%) did not provide input. On whether they used a public address system to mobilize the communities $11(31.43 \%)$ respondents said yes, while $17(48.57 \%)$ respondents said no they did not use a loud speaker to mobilize people. 7 (20\%) respondents did not answer. The findings also show that $10(28.57 \%)$ respondents used Radio/ television interviews or announcements while 17 (48.57\%) did not and another $8(22.86 \%)$ did not give an opinion. $7(20 \%)$ respondents had other means for community mobilization while $24(68.57 \%)$ had no input. These findings conclude that most respondents $27(77.14 \%)$ use education talks to conduct communication and social mobilization.

This study indicates that the various health facilities in the county have adopted a mix of communication and demand creation strategies consisting of the various channel of relaying messages. They use education talks almost as much as they use school-based activities to raise awareness of the available vaccination services. other means also have been significantly been employed like, using loud speakers, posters and signs, health fairs, and the mass media like radios and such. The study agrees with Maynard, Kane, \& Hadler, (2009) that communication plays a major role in informing families when and where these expanded services are available significantly impacting on coverage.

The study however shows a need to utilize further mass media due to the extensive coverage and agrees with the World Health Organization, (2009) that says promoting utilization or, in other words, creating consumer demand for immunization services is appropriate strategy in the majority of developing countries where the principal challenge has been to rapidly increase immunization coverage rates. Mass media have played an important role in these demand creation strategies, and a number of countries have additionally mobilized thousands of individuals from multiple sectors of society to help deliver people to immunization services, or services to people, on the occasion of special national immunization days.

\section{Conclusion}

The study concluded that planning done is not effective to enhance planning outcomes in preventing and promoting EPI vaccination at the county. The planning is not able to influence the availability of guidelines and manuals, solve problems of introducing new vaccines and in establishing a criterion to identify risk areas. Devolution and decentralization in relation to immunization program management has also not impacted the planning outcomes on the availability of guidelines and manuals, solve problems and in establishing a criterion to identify risk areas. All this is despite an allocation of resources to facilitate programmed activities, estimation of needs for vaccines, syringes and supplies for vaccination in the health/ catchment area and a presumed reflection of the planning activities to reality in the catchment area.

On organization and coordination, health facilities have not collaborated with enough stakeholders to assist them provide EPI services including vaccination, epidemiological surveillance training, and communication and social mobilization. Consequently, the health care sectors are having to perform all these activities without support of key stakeholders and hence the need to bring on board key sectors such as community organizations and leaders, education sector, administration, private sector, church and security sectors to enhance EPI vaccination effectiveness. 
From the study, we can conclude that training conducted on health workers mandated to carry out EPI vaccination has been very effective. They are equipped with the appropriate skills to carry out planning as well as implementation of vaccination activities specific to the needs of areas they serve as well as how to correctly manage the identified VPDs in the areas. In addition, these health workers are equipped with the knowledge of the basic yet key steps needed to increase coverage of vaccination programs such as compiling of local immunizations data, analyzing the data then using it for planning, prioritizing and problem identification, and planning and monitoring the EPI program.

The study has shown the non-extensive utilization of the various means of communication in to reaching people. The health facilities however have been concentrating much on education talks and school-based activities which are communication strategies that do not reach an extensive part of the population. The information provided in these education forums and in schools does not really give a good representation of the entire population and more effective channels need to be utilized as the county aims to get past the challenge of coverage.

\section{Recommendation}

\subsection{The Study Recommended That}

The county health department should ensure that the planning process is desirable in that, it is participatory, realistic, and flexible, so that the plan is a practical document. The planning of the EPI should begin with studying and assessing the health of the community, and the county, using local, national, regional and global policies as a framework. Health situation analysis should include, among other things, an evaluation of the following pieces of information related to vaccine--preventable diseases (VPDs), as well as an assessment of the availability of effective vaccination services in the national network, the population's level of education and participation and the integration of the EPI with other programs, all in order to guide activities and rationalize the use of resources

To be eligible for new EPI vaccine or financial support, healthcare centers need to demonstrate a basic functionality of their coordination. In order to do this, they should adhere to the requirements outlined in our guidance document. There is also need to bring on board key sectors such as community organizations and leaders, education sector, administration, private sector, church and security sectors to enhance EPI vaccination effectiveness.

What the county health department needs to do is to maintain the impressive number of well-trained health workers tasked to manage EPI vaccination. The departments should also ensure that the few health workers that have not enough training or have not covered certain topics are trained on them and equipped to properly manage EPI vaccination.

In order to mobilize people in large numbers, the county department should ensure that health facilities prioritize the use of channels that reach the largest group of people like mass media. Mass media goes beyond the barrier of illiteracy that is created by posters and signs as well as surpasses the small population targeted in school-based activities and education talks.

\section{References}

i. Amin, R., Pierre, M. S., Ahmed, A., \& Haq, R. (2011). Integration of an essential services package (ESP) in child and reproductive health and family planning with a micro-credit program for poor women: experience from a pilot project in rural Bangladesh. World Development, 29(9), 1611-1621.

ii. Arevshatian, L., Clements, C. J., Lwanga, S. K., Misore, A. O., Ndumbe, P., Seward, J. F., \& Taylor, P. (2007). An evaluation of infant immunization in Africa: is a transformation in progress? Bulletin of the World Health Organization, 85(6), 449-457.

iii. Aronson, S. B., Goodner, E. K., Yamamoto, E., \& Foreman, M. (2015). Mechanisms of the Host Response in the Eye: I. Changes in the Anterior Eye Following Immunization to a Heterologous Antigen. Archives of Ophthalmology, 73(3), 402-412.

iv. Brugha, R., Starling, M., \& Walt, G. (2012). GAVI, the first steps: lessons for the Global Fund. The Lancet, 359(9304), 435-438.

v. Cutts, F. T. (2008). Advances and challenges for the expanded programme on immunization. British medical bulletin, 54(2), 445-461.

vi. DeRoeck, D., Bawazir, S. A., Carrasco, P., Kaddar, M., Brooks, A., Fitzsimmons, J., \& Andrus, J. (2016). Regional group purchasing of vaccines: review of the Pan American Health Organization EPI revolving fund and the Gulf Cooperation Council group purchasing program. The International journal of health planning and management, 21(1), 23-43.

vii. Henderson, R. H., \& Sundaresan, T. (2012). Cluster sampling to assess immunization coverage: a review of experience with a simplified sampling method. Bulletin of the World Health Organization, 60(2), 253.

viii. Henderson, R. H., \& Sundaresan, T. (2012). Cluster sampling to assess immunization coverage: a review of experience with a simplified sampling method. Bulletin of the World Health Organization, 60(2), 253.

ix. Hesseling, A. C., Caldwell, J., Cotton, M. F., Eley, B. S., Jaspan, H. B., Jennings, K., ... \& Schaaf, H. S. (2009). BCG vaccination in South African HIV-exposed infants: risks and benefits. SAMJ: South African Medical Journal, 99(2), 88-91.

x. Jewkes, R. K., Dunkle, K., Nduna, M., \& Shai, N. (2010). Intimate partner violence, relationship power inequity, and incidence of HIV infection in young women in South Africa: a cohort study. The lancet, 376(9734), 41-48.

xi. JOH, T. H., \& GOLDSTEIN, M. (2013). Isolation and characterization of multiple forms of phenylethanolamine $\mathrm{N}$ methyltransferase. Molecular pharmacology, 9(1), 117-129.

xii. Kim-Farley, R. (2012). Global immunization. Annual Review of Public Health, 13(1), 223-237. 
xiii. Koumaré, A. K., Maïga, A., Togola, B., Coulibaly, B., Traore, D., Haidara, F., ... \& Dramé, S. (2009). Evaluation of immunization coverage within the Expanded Program on Immunization in Kita Circle, Mali: a cross-sectional survey. BMC international health and human rights, 9(1),

xiv. Loevinsohn, B., Hong, R., \& Gauri, V. (2016). Will more inputs improve the delivery of health services?: Analysis of district vaccination coverage in Pakistan. The International journal of health planning and management, 21(1), 4554 .

xv. Mangrio, N. K., Alam, M. M., \& Shaikh, B. T. (2008). Is Expanded Programme on Immunization doing enough? Viewpoint of health workers and managers in Sindh, Pakistan. JPMA. The Journal of the Pakistan Medical Association, 58(2), 64.

xvi. Maynard, J. E., Kane, M. A., \& Hadler, S. C. (2009). Global control of hepatitis B through vaccination: role of hepatitis B vaccine in the Expanded Programme on Immunization. Clinical Infectious Diseases, 11(Supplement_3), S574S578.

xvii. Moïsi, J. C., Kabuka, J., Mitingi, D., Levine, O. S., \& Scott, J. A. G. (2010). Spatial and socio-demographic predictors of time-to-immunization in a rural area in Kenya: Is equity attainable?. Vaccine, 28(35), 5725-5730.

xviii. Ndiritu, M., Cowgill, K. D., Ismail, A., Chiphatsi, S., Kamau, T., Fegan, G., ... \& Scott, J. A. G. (2016). Immunization coverage and risk factors for failure to immunize within the Expanded Programme on Immunization in Kenya after introduction of new Haemophilus influenzae type $b$ and hepatitis b virus antigens. BMC Public health, 6(1), 132.

xix. Olivé, J. M., Risi Jr, J. B., \& de Quadros, C. A. (2007). National immunization days: experience in Latin America. The Journal of infectious diseases, 175(Supplement_1), S189-S193.

xx. Pickering, L. K., Baker, C. J., Freed, G. L., Gall, S. A., Grogg, S. E., Poland, G. A., ... \& Zimmerman, R. K. (2009). Immunization programs for infants, children, adolescents, and adults: clinical practice guidelines by the Infectious Diseases Society of America. Clinical Infectious Diseases, 49(6), 817-840.

xxi. Prinja, S., Gupta, M., Singh, A., \& Kumar, R. (2010). Effectiveness of planning and management interventions for improving age-appropriate immunization in rural India. Bulletin of the World Health Organization, 88(2), 97-103.

xxii. Schlegel, W., \& Raptis, S. (2016). A reliable method for generating antibodies against pancreozymin, secretin and gastrin. Clinica Chimica Acta, 73(3), 439-444.

xxiii. $\quad$ Tsebe, K. V., Burnett, R. J., Hlungwani, N. P., Sibara, M. M., Venter, P. A., \& Mphahlele, M. J. (2011). The first five years of universal hepatitis B vaccination in South Africa: evidence for elimination of HBsAg carriage in under 5year-olds. Vaccine, 19(28), 3919-3926.

xxiv. Turner, A. G., Magnani, R. J., \& Shuaib, M. (2016). A not quite as quick but much cleaner alternative to the Expanded Programme on Immunization (EPI) Cluster Survey design. International journal of epidemiology, 25(1), 198-203.

xxv. Wakadha, H., Chandir, S., Were, E. V., Rubin, A., Obor, D., Levine, O. S., ... \& Feikin, D. R. (2013). The feasibility of using mobile-phone based SMS reminders and conditional cash transfers to improve timely immunization in rural Kenya. Vaccine, 31(6), 987-993.

xxvi. World Health Organization. (2015). Integrated management of the sick child.

xxvii. Ijsselmuiden, W. J., \& HGV, B. (2007). Notification of five of the EPI target diseases in South Africa-an assessment of disease and vaccination reporting. South African Medical Journal, 72(5), 311-316.

xxviii. Uskun, E., Uskun, S. B., Uysalgenc, M., \& Yagız, M. (2008). Effectiveness of a training intervention on immunization to increase knowledge of primary healthcare workers and vaccination coverage rates. Public Health, 122(9), 949958.

xxix. Schellenberg, D., Menendez, C., Kahigwa, E., Aponte, J., Vidal, J., Tanner, M., ... \& Alonso, P. (2011). Intermittent treatment for malaria and anaemia control at time of routine vaccinations in Tanzanian infants: a randomised, placebo-controlled trial. The Lancet, 357(9267), 1471-1477.

xxx. Maynard, J. E., Kane, M. A., \& Hadler, S. C. (2009). Global control of hepatitis B through vaccination: role of hepatitis B vaccine in the Expanded Programme on Immunization. Clinical Infectious Diseases, 11(Supplement 3), S574S578.

xxxi. $\quad$ Ohrr, H., Tandan, J. B., Sohn, Y. M., Shin, S. H., Pradhan, D. P., \& Halstead, S. B. (2015). Effect of single dose of SA 1414-2 vaccine 1 year after immunisation in Nepalese children with Japanese encephalitis: a case-control study. The Lancet, 366(9494), 1375-1378.

xxxii. Assi, T. M., Brown, S. T., Djibo, A., Norman, B. A., Rajgopal, J., Welling, J. S., ... \& Connor, D. L. (2011). Impact of changing the measles vaccine vial size on Niger's vaccine supply chain: a computational model. BMC Public Health, $11(1), 425$.

xxxiii. Levine, O. S., Bloom, D. E., Cherian, T., de Quadros, C., Sow, S., Wecker, J., ... \& Greenwood, B. (2011). The future of immunisation policy, implementation, and financing. The Lancet, 378(9789), 439-448.

xxxiv. Hutin, Y. J., \& Chen, R. T. (2009). Injection safety: a global challenge. Bulletin of the World Health Organization, 77(10), 787.

xxxv. Djingarey, M. H., Barry, R, Bonkoungou, M., Tiendrebeogo, S., Sebgo, R., Kandolo, D., ... \& Hugonnet, S. (2012). Effectively introducing a new meningococcal A conjugate vaccine in Africa: the Burkina Faso experience. Vaccine, 30, B40-B45.

xxxvi. Mahoney, R. T., \& Maynard, J. E. (2009). The introduction of new vaccines into developing countries. Vaccine, 17(7), 646-652. 
xxxvii. Adegbola, R. A., Secka, O., Lahai, G., Lloyd-Evans, N., Njie, A., Usen, S., ... \& Mulholland, K. (2015). Elimination of Haemophilus influenzae type $b(\mathrm{Hib})$ disease from The Gambia after the introduction of routine immunisation with a Hib conjugate vaccine: a prospective study. The Lancet, 366(9480), 144-150.

xxxviii. Lee, B. Y., Cakouros, B. E., Assi, T. M., Connor, D. L., Welling, J., Kone, S., ... \& Brown, S. T. (2012). The impact of making vaccines thermostable in Niger's vaccine supply chain. Vaccine, 30(38), 5637-5643.

xxxix. Matthias, D. M., Robertson, J., Garrison, M. M., Newland, S., \& Nelson, C. (2007). Freezing temperatures in the vaccine cold chain: a systematic literature review. Vaccine, 25(20), 3980-3986.

xl. Haidari, Leila A., Diana L. Connor, Angela R. Wateska, Shawn T. Brown, Leslie E. Mueller, Bryan A. Norman, Michelle M. Schmitz et al. (2013) "Augmenting transport versus increasing cold storage to improve vaccine supply chains." PloS one 8, no. 5 e64303.

xli. Wirkas, T., Toikilik, S., Miller, N., Morgan, C., \& Clements, C. J. (2007). A vaccine cold chain freezing study in PNG highlights technology needs for hot climate countries. Vaccine, 25(4), 691-697.

xlii. Lee, B. Y., Assi, T. M., Rajgopal, J., Norman, B. A., Chen, S. I., Brown, S. T., ... \& Connor, D. L. (2012). Impact of introducing the pneumococcal and rotavirus vaccines into the routine immunization program in Niger. American journal of public health, 102(2), 269-276.

xliii. Uskun, E., Uskun, S. B., Uysalgenc, M., \& Yagız, M. (2008). Effectiveness of a training intervention on immunization to increase knowledge of primary healthcare workers and vaccination coverage rates. Public Health, 122(9), 949958.

xliv. Moses Ndiritu, ${ }^{1}$ Karen D Cowgill, ${ }^{2}$ Amina Ismail, ${ }^{3}$ Salome Chiphatsi, ${ }^{4}$ Tatu Kamau, ${ }^{3}$ Gregory Fegan, ${ }^{1,5}$ Daniel $\mathrm{R}$ Feikin, ${ }^{6}$ Charles RJC Newton, ${ }^{1,7}$ and J Anthony G Scott (2016) on Immunization coverage and risk factors for failure to immunize within the Expanded Programme on Immunization in Kenya after introduction of new Haemophilus influenzae type $\mathrm{b}$ and hepatitis b virus antigens. Public health

xlv. Gagnon, R., Primeau, M. N., Des Roches, A., Lemire, C., Kagan, R., Carr, S., ... \& PHAC-CIHR Influenza Research Network (PCIRN. (2010). Safe vaccination of patients with egg allergy with an adjuvanted pandemic H1N1 vaccine. Journal of Allergy and Clinical Immunology, 126(2), 317-323.

xlvi. Callow, L. L., \& Dalgliesh, R. J. (2010). The development of effective, safe vaccination against babesiosis and anaplasmosis in Australia. In Tick and tick-borne diseases. Proceedings of the Symposium of the 56th Annual Conference of the Australian Veterinary Association (pp. 4-8).

xlvii. Des Roches, A., Samaan, K., Graham, F., Lacombe-Barrios, J., Paradis, J., Paradis, L., \& De Serres, G. (2015). Safe vaccination of patients with egg allergy by using live attenuated influenza vaccine. Journal of Allergy and Clinical Immunology. In Practice, 3(1), 138.

xlviii. Schultz, R. D. (2010). Considerations in designing effective and safe vaccination programs for dogs. Recent Advances in Canine Infectious Diseases. International Veterinary Information Service.

xlix. Weiss, P. (2011, June). Safe vaccination against hepatitis B virus and discontinuation of hepatitis B immune globulin treatment in a liver transplanted patient. In Transplantation proceedings (Vol. 32, No. 4, pp. 712-713). Elsevier.

1. Scharpé, J., Evenepoel, P., Maes, B., Bammens, B., Claes, K., Osterhaus, A. D., ... \& Peetermans, W. E. (2008). Influenza vaccination is efficacious and safe in renal transplant recipients. American Journal of Transplantation, 8(2), 332337.

li. Stilo, S. A., \& Murray, R. M. (2010). The epidemology of schizophrenia: replacing dogma with knowledge. Dialogues in clinical neuroscience, 12(3), 305.

lii. Remennick, L. I. (2011). Epidemology and determinants of induced abortion in the USSR. Social science \& medicine, 33(7), 841-848.

liii. Cannon, M., Coughlan, H., Clarke, M., Harley, M., \& Kelleher, I. (2013). The Mental Health of Young People in Ireland: A report of the Psychiatric Epidemology Research across the Lifespan (PERL) Group.

liv. Baranyiová, E., Holub, A., Martinikova, M., Nečas, A., \& Zatloukal, J. (2013). Epidemology of Intraspecies Bite Wounds in Dogs in the Czech Republic. Acta Veterinaria Brno, 72(1), 55-62.

lv. De Vos, A. J., \& Every, R. (2011). Epidemology and control of bovine babesiosis in the Natal Midlands. In Tick biology and control: proceedings of an International Conference January 27-29, 1981/ edited by GB Whitehead and JD Gibson. Grahamstown, South Africa: Tick Research Unit, Rhodes University, [1981].

lvi. Varricchio, F., Iskander, J., Destefano, F., Ball, R., Pless, R., Braun, M. M., \& Chen, R. T. (2014). Understanding vaccine safety information from the vaccine adverse event reporting system. The Pediatric infectious disease journal, 23(4), 287-294.

lvii. Siddiqi, N., Siddiqi, A. E., Nisar, N., \& Khan, A. (2010). Mothers' knowledge about EPI and its relation with ageappropriate vaccination of infants in peri-urban Karachi. JPMA. The Journal of the Pakistan Medical Association, 60(11), 940-944.

lviii. Adeiga, A., Omilabu, S. A., Audu, R. A., Sanni, F. A., Lakehinde, G. F., Balogun, O., \& Olagbaju, O. (2015). Infant immunization coverage in difficult-to-reach area of Lagos metropolis. African Journal of Clinical and Experimental Microbiology, 6(3), 227-231.

lix. Kidane, T., Yigzaw, A., Sahilemariam, Y., Bulto, T., Mengistu, H., Belay, T., ... \& Olusegun, B. (2008). National EPI coverage survey report in Ethiopia, 2006. Ethiopian Journal of Health Development, 22(2), 148-157.

lx. Loevinsohn, B. P. (2009). Missed opportunities for immunization during visits for curative care: practical reasons for their occurrence. The American journal of tropical medicine and hygiene, 41(3), 255-258. 
lxi. Van Tran, D., Van Thuan, C., Tuan, T., Dung, P. H., Persson, L., \& Grabe, M. (2011). Survey on immunization, diarrhoeal disease and mortality in Quang Ninh Province, Vietnam. Journal of Tropical Pediatrics, 37(6), 280-285.

lxii. Mavimbe, J. C., Braa, J., \& Bjune, G. (2015). Assessing immunization data quality from routine reports in Mozambique. BMC public health, 5(1), 108.

lxiii. Moore, D. C., Bridenbaugh, L. D., Bagdi, P. A., Bridenbaugh, P. O., \& Stander, H. (2008). The present status of spinal (subarachnoid) and epidural (peridural) block: a comparison of the two technics. Anesthesia \& Analgesia, 47(1), 40-49.

lxiv. Turner, A. G., Magnani, R. J., \& Shuaib, M. (2016). A not quite as quick but much cleaner alternative to the Expanded Programme on Immunization (EPI) Cluster Survey design. International journal of epidemiology, 25(1), 198-203.

lxv. World Health Organization. (2009). WHO vaccine-preventable diseases: monitoring system: 2009 global summary.

lxvi. Schellenberg, D., Menendez, C., Kahigwa, E., Aponte, J., Vidal, J., Tanner, M., ... \& Alonso, P. (2011). Intermittent treatment for malaria and anaemia control at time of routine vaccinations in Tanzanian infants: a randomised, placebo-controlled trial. The Lancet, 357(9267), 1471-1477.

lxvii. Ellenberg, S. S., \& Chen, R. T. (2007). The complicated task of monitoring vaccine safety. Public health reports, 112(1), 10.

lxviii. Brugha, R., Starling, M., \& Walt, G. (2012). GAVI, the first steps: lessons for the Global Fund. The Lancet, 359(9304), 435-438.

lxix. Aylward, B., Lloyd, J., Zaffran, M., McNair-Scott, R., \& Evans, P. (2015). Reducing the risk of unsafe injections in immunization programmes: financial and operational implications of various injection technologies. Bulletin of the World Health Organization, 73(4), 531.

lxx. Hutchins, S. S., Jansen, H. A., Robertson, S. E., Evans, P., \& Kim-Farley, R. J. (2013). Studies of missed opportunities for immunization in developing and industrialized countries. Bulletin of the World Health Organization, 71(5), 549

\section{Appendix}

Questionnaire for Vaccination Health Officials in Uasin Gishu County

Republic of Kenya

County Government of Uasin Gishu

Department of Health Services

Preventive \& Promotive Services

\begin{tabular}{|c|c|c|c|}
\hline \multicolumn{3}{|c|}{ General Information } \\
\hline Date of interview & \multicolumn{1}{|c|}{} \\
\hline Sub county & & wnterviewer's name: & \\
\hline Health facility Name: & & Type of facility: & \\
\hline Facility's hours of operation: & Urban/ Rural & Days & \\
\hline Area: & & Days: & \\
\hline Facility's vaccination hours: & & Population age 1 & \\
\hline $\begin{array}{c}\text { Population of children under 1 } \\
\text { year: }\end{array}$ & $\begin{array}{c}\text { Total population of } \\
\text { the health area: }\end{array}$ & \\
\hline \begin{tabular}{l} 
Population of pregnant women: \\
\hline
\end{tabular} & &
\end{tabular}

Table 25

\begin{tabular}{|l|l|l|l|l|}
\hline Cadre & Functions in The Epi & Duration Position & $\begin{array}{c}\text { Permanent Or Temporary } \\
\text { Deployed In The Epi }\end{array}$ & $\begin{array}{c}\text { Other Functions In } \\
\text { The Health Facility }\end{array}$ \\
\hline & & & & \\
\hline & & & & \\
\hline & & & & \\
\hline & & & & \\
\hline & & & & \\
\hline
\end{tabular}

Table 26: Staffs Participating in EPI Activities Indicate the Number of Human Resources 


\begin{tabular}{|c|c|c|c|c|c|c|}
\hline \multirow[t]{2}{*}{ Components } & \multicolumn{2}{|r|}{ Evaluation Criteria } & \multicolumn{3}{|c|}{ Response } & \multirow[t]{2}{*}{ Comments - } \\
\hline & & & Yes & No & NA & \\
\hline \multirow{26}{*}{ 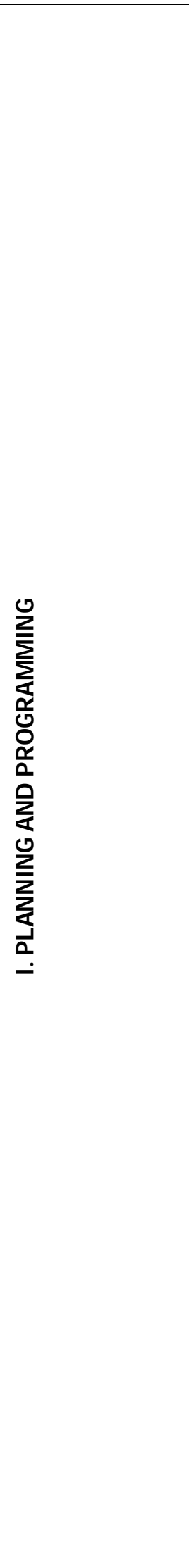 } & Ask & $\begin{array}{c}\text { 1.1 Do you have } \\
\text { microprogramming that includes } \\
\text { goals, activities, a timetable, and } \\
\text { budget? }\end{array}$ & & & & If not, why? \\
\hline & Verify & & & & & \\
\hline & \multirow[t]{13}{*}{ Ask } & $\begin{array}{l}1.2 \text { Does the assigned target } \\
\text { population reflect the reality of the } \\
\text { catchment area? }\end{array}$ & & & & If not, why? \\
\hline & & $\begin{array}{l}\text { 1.3 Are the following guidelines or } \\
\text { manuals available: }\end{array}$ & & & & \\
\hline & & $\begin{array}{c}\text { 1.3.1 Epidemiological surveillance } \\
\text { of vaccine-preventable diseases } \\
\text { (VPD) }\end{array}$ & & & & \\
\hline & & 1.3.2 New vaccines & & & & \\
\hline & & $\begin{array}{c}\text { 1.3.3 } \begin{array}{l}\text { EPI standards operating } \\
\text { procedures (SOPs) }\end{array} \\
\end{array}$ & & & & \\
\hline & & $\begin{array}{l}\text { 1.4 Were there any problems with } \\
\text { the introduction of new vaccines? }\end{array}$ & & & & $\begin{array}{l}\text { If yes, in which } \\
\text { components? }\end{array}$ \\
\hline & & $\begin{array}{ll}1.4 .1 & \text { Training } \\
\end{array}$ & & & & \\
\hline & & 1.4.2 Cold chain & & & & \\
\hline & & $\begin{array}{cc}1.4 .3 & \text { Logistics } \\
\end{array}$ & & & & \\
\hline & & $\begin{array}{l}\text { 1.4.4 Administration of the } \\
\text { vaccine }\end{array}$ & & & & \\
\hline & & 1.4.5 Information system & & & & \\
\hline & & $\begin{array}{ll}\text { 1.4.6 } & \begin{array}{l}\text { Mobilization and mass } \\
\text { communication }\end{array} \\
\end{array}$ & & & & \\
\hline & & $\begin{array}{ll}1.4 .7 & \text { Other } \\
\end{array}$ & & & & Specify. \\
\hline & Verify & $\begin{array}{l}1.5 \text { Is there any record (list or } \\
\text { map) of the communities in their } \\
\text { health area/ catchment area? }\end{array}$ & & & & \\
\hline & \multirow[t]{6}{*}{ Ask } & $\begin{array}{l}\text { 1.6 What criteria are used to } \\
\text { identify risk areas? }\end{array}$ & & & & \\
\hline & & 1.6.1 Vaccination coverage & & & & \\
\hline & & $\begin{array}{c}\text { 1.6.2 } \\
\begin{array}{l}\text { Marginalized, overcrowded, } \\
\text { or remote areas }\end{array}\end{array}$ & & & & \\
\hline & & 1.6.3 traveler populations & & & & \\
\hline & & $\begin{array}{cl}1.6 .4 & \begin{array}{l}\text { Reports of cases and } \\
\text { outbreaks }\end{array} \\
\end{array}$ & & & & \\
\hline & & 1.6.5 Other & & & & Specify. \\
\hline & Verify & & & & & \\
\hline & \multirow[t]{3}{*}{ Ask } & $\begin{array}{l}1.7 \text { Is there an estimate of needs } \\
\text { for vaccines, syringes, and supplies } \\
\text { for vaccination in the health } \\
\text { area/ catchment area? }\end{array}$ & & & & \\
\hline & & $\begin{array}{c}1.8 \text { Have resources been allocated } \\
\text { to facilitate programmed activities } \\
\text { (transportation, fuel, incidentals, } \\
\text { paper products, etc.)? }\end{array}$ & & & & Specify. \\
\hline & & $\begin{array}{c}1.9 \text { Has devolution/ } \\
\text { decentralization had any impact } \\
\text { (positive or negative) on } \\
\text { immunization program } \\
\text { management? }\end{array}$ & & & & \\
\hline \multirow{2}{*}{ 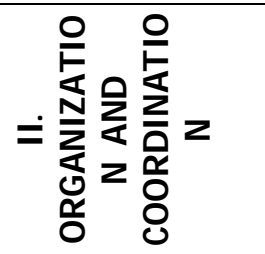 } & \multirow[t]{2}{*}{ Observe } & $\begin{array}{l}2.1 \text { Is there an adequate physical } \\
\text { space (exclusive use, clean, } \\
\text { organized, with washbasin) for } \\
\text { vaccination activities? }\end{array}$ & & & & $\begin{array}{l}\text { It is considered adequate } \\
\text { if the EPI shares space } \\
\text { with growth and } \\
\text { development monitoring. }\end{array}$ \\
\hline & & $\begin{array}{l}\text { 2.2 Can the public easily identify } \\
\text { vaccination service? }\end{array}$ & & & & \\
\hline
\end{tabular}




\begin{tabular}{|c|c|c|c|}
\hline & & $\begin{array}{l}\text { 2.3 With which sectors does the } \\
\text { facility collaborate with? }\end{array}$ & $\begin{array}{l}\text { Ask for examples in each } \\
\text { case and note as } \\
\text { appropriate. }\end{array}$ \\
\hline & & $\begin{array}{cc}\text { 2.3.1 Community organizations } \\
\text { and leaders }\end{array}$ & \\
\hline & & 2.3.2 Education sector & \\
\hline & & 2.3.3 $\quad$ Administration & \\
\hline & & 2.3.4 Private sector & \\
\hline & & 2.3.5 Church & \\
\hline & & 2.3.6 $\quad$ security & \\
\hline & & $\begin{array}{ll}2.3 .7 & \text { Others } \\
\end{array}$ & Specify. \\
\hline & & $\begin{array}{l}2.4 \text { What types of activities are } \\
\text { supported with other institutions? }\end{array}$ & \\
\hline & & $\begin{array}{cc}2.4 .1 & \text { Vaccination } \\
\end{array}$ & \\
\hline & & 2.4.2 Epidemiological surveillance & \\
\hline & & $2.4 .3 \quad$ Training & \\
\hline & & $\begin{array}{cc}\text { 2.4.4 Communication and social } \\
\text { mobilization }\end{array}$ & \\
\hline & & $\begin{aligned} & 2.4 .5 \text { Others } \\
&\end{aligned}$ & \\
\hline & Ask & 3.1 When was the last time that & \\
\hline & & $\begin{array}{c}\text { you received training in } \\
\text { immunization program activities? }\end{array}$ & Specify. \\
\hline & & 3.2 What topics were covered? & \\
\hline & & 3.2.1 $\quad$ Planning and programming & \\
\hline & & $3.2 .2 \quad$ Cold chain & \\
\hline & & 3.2.3 Vaccine safety & \\
\hline & & 3.2.4 Information systems & \\
\hline & & $\begin{array}{c}\text { 3.2.5 Investigation and } \\
\text { management of AEFI }\end{array}$ & \\
\hline & & 3.2.6 $\quad$ Epidemiological surveillance & \\
\hline & & 3.2 .7 Coverage monitoring & \\
\hline & & 3.2.8 Introduction of new vaccines & Specify the vaccine. \\
\hline & & $\begin{array}{ll}3.2 .9 & \text { Others } \\
\end{array}$ & Specify. \\
\hline$z$ & Evaluate & $\begin{array}{l}\text { 3.3 Evaluate whether the } \\
\text { interview ee is familiar with the EPI } \\
\text { vaccination schedule }\end{array}$ & \\
\hline 目 & & $\begin{array}{c}3.4 \text { Evaluate whether the } \\
\text { interviewee is familiar with the } \\
\text { concept of drop-out or default rate. }\end{array}$ & $\begin{array}{c}\text { Request that s/ he } \\
\text { explain the drop-out rate } \\
\text { for PENTA1/ PENTA3 } \\
\text { and evaluate whether the } \\
\text { response is correct. }\end{array}$ \\
\hline & & $\begin{array}{l}\text { 3.5 Evaluate whether the } \\
\text { interviewee knows how to manage } \\
\text { the following cases: }\end{array}$ & \\
\hline & & $\begin{array}{l}\text { 3.5.1 Which vaccine would you } \\
\text { administer to a 7-month- old who } \\
\text { has had one dose of BCG, one of } \\
\text { PENTA, and one of OPV, and the } \\
\text { doses of PENTA and OPV were } \\
\text { administered five weeks ago? }\end{array}$ & $\begin{array}{l}\text { The correct response is } \\
\text { "the second dose of } \\
\text { PENTA and OPV." Other } \\
\text { vaccines in the evaluated } \\
\text { EPI vaccination schedule } \\
\text { should be taken into } \\
\text { account. }\end{array}$ \\
\hline & & $\begin{array}{l}\text { 3.5.2 Which vaccines would you } \\
\text { administer to a } 15 \text {-month old child } \\
\text { who has never been vaccinated? }\end{array}$ & $\begin{array}{l}\text { The correct response is } \\
\text { "BCG, PENTA, OPV and } \\
\text { MR, PCV." }\end{array}$ \\
\hline 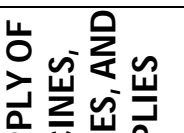 & Verify & $\begin{array}{l}4.1 \text { Is there an up-to-date } \\
\text { inventory system for the movement } \\
\text { of biologicals? }\end{array}$ & \\
\hline 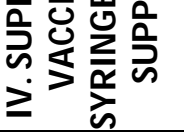 & & $\begin{array}{l}4.2 \text { Is there an up-to-date } \\
\text { inventory system for the movement } \\
\text { of syringes and supplies? }\end{array}$ & \\
\hline
\end{tabular}




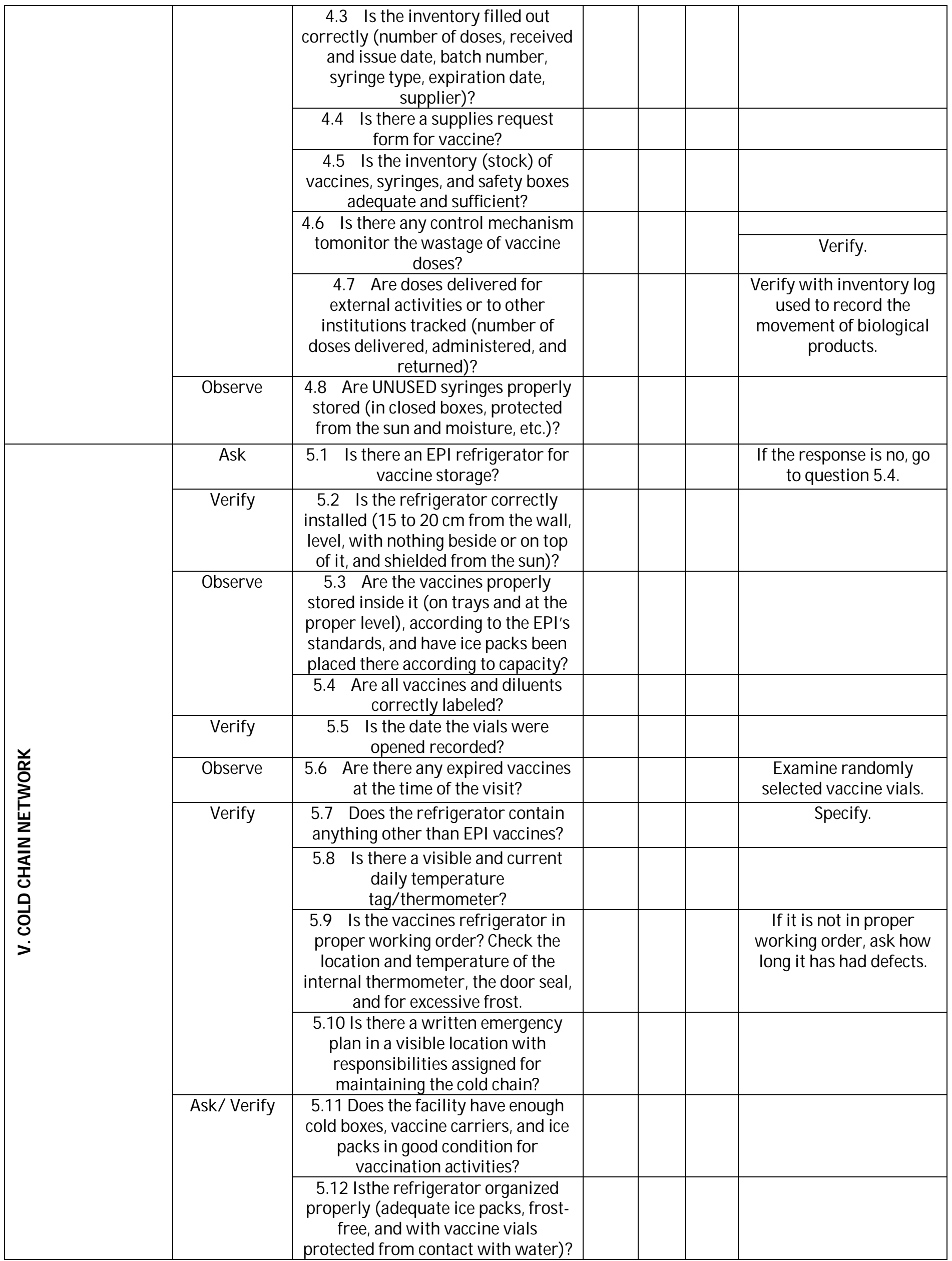




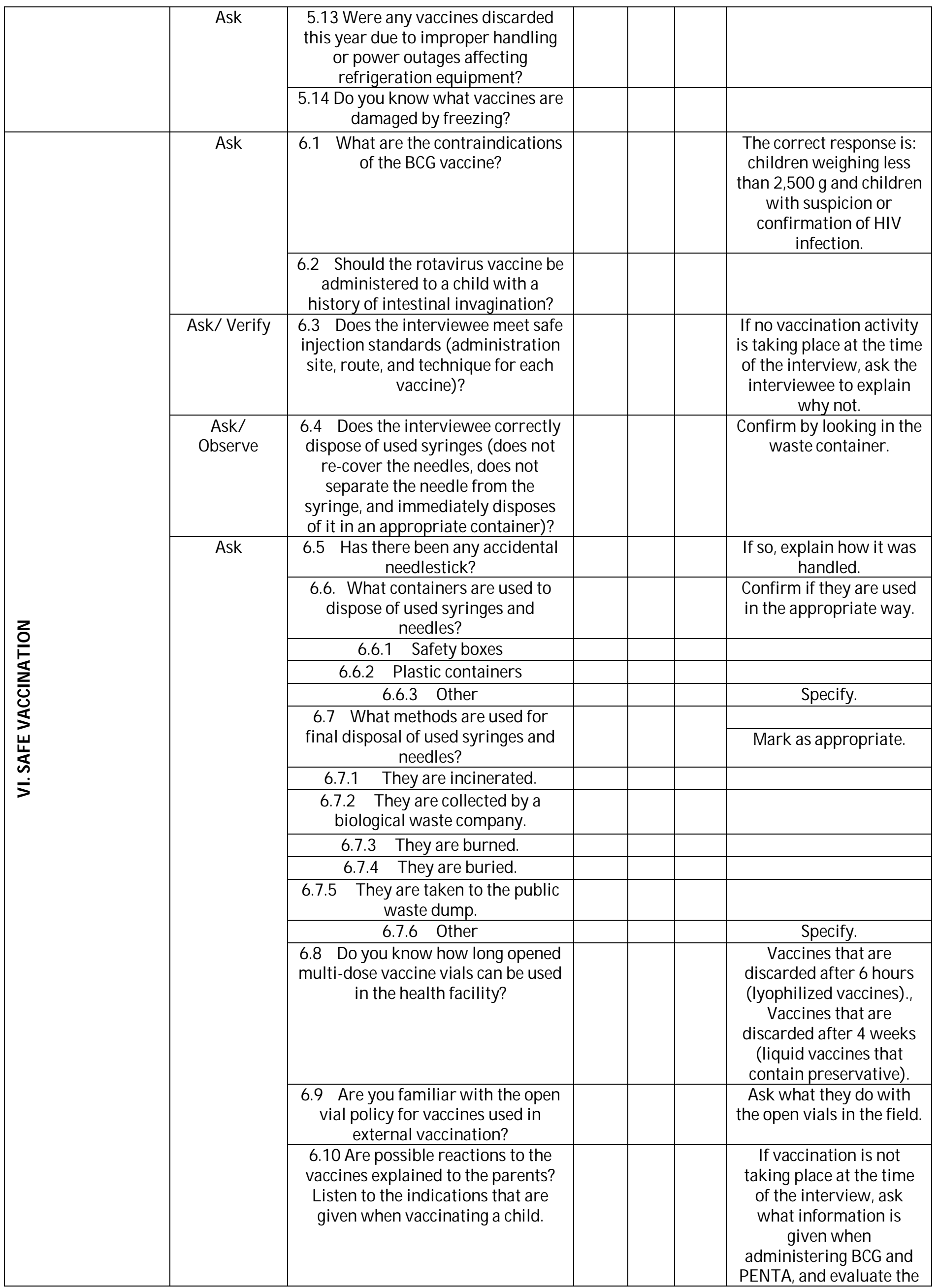




\begin{tabular}{|c|c|c|c|}
\hline & & & response. \\
\hline & & $\begin{array}{c}\text { 6.11 Is there a form for reporting } \\
\text { AEFI? }\end{array}$ & \\
\hline & & $\begin{array}{l}\text { 6.12 Are you familiar with the AEFI } \\
\text { reporting procedures (what to } \\
\text { report and to whom)? }\end{array}$ & $\begin{array}{l}\text { Request that s/ he } \\
\text { explain and evaluate the } \\
\text { response. }\end{array}$ \\
\hline & & $\begin{array}{l}\text { 6.13 If you reported an AEFI this } \\
\text { year, did you receive feedback? }\end{array}$ & $\begin{array}{l}\text { Specify the number of } \\
\text { cases. }\end{array}$ \\
\hline & & $\begin{array}{l}\text { 6.14 How many reported AEFI were } \\
\text { classified as programmatic errors? }\end{array}$ & Specify. \\
\hline & Ask/ Verify & $\begin{array}{l}6.15 \text { What vaccines have you } \\
\text { received as a health worker? }\end{array}$ & $\begin{array}{l}\text { Request the vaccination } \\
\text { card and review the } \\
\text { schedule. }\end{array}$ \\
\hline & Ask & $\begin{array}{l}7.1 \text { Is there any vaccine that is not } \\
\text { administered daily in the health } \\
\text { facility? }\end{array}$ & $\begin{array}{l}\text { Specify the reason and } \\
\text { the vaccine. }\end{array}$ \\
\hline & & $\begin{array}{l}7.2 \text { What strategies are used to } \\
\text { provide vaccination services? }\end{array}$ & \\
\hline & & $\begin{array}{l}\text { 7nstitutional (in the health } \\
\text { facility) }\end{array}$ & \\
\hline & & 7.2.2 House to house & \\
\hline & & $7.2 .3 \quad$ Referrals & \\
\hline 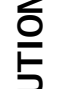 & & $\begin{array}{cl}7.2 .4 & \begin{array}{l}\text { Fixed or mobile posts } \\
\text { (external) }\end{array}\end{array}$ & \\
\hline 8 & & $7.2 .5 \quad$ Other & Specify. \\
\hline 厌 & & $\begin{array}{l}\text { 7.3 Is the timetable for off-site } \\
\text { vaccination followed? }\end{array}$ & If not, why? \\
\hline & & $\begin{array}{l}7.4 \text { Are new vaccines administered } \\
\text { during external activities? }\end{array}$ & If not, why? \\
\hline & & $\begin{array}{c}7.5 \text { Have there been any } \\
\text { interruptions in the administration } \\
\text { of a particular vaccine this year? }\end{array}$ & $\begin{array}{l}\text { Which vaccine, why and } \\
\text { how often? }\end{array}$ \\
\hline & & 7.6 Are there strategies for & \\
\hline & & $\begin{array}{l}\text { following up on individuals who } \\
\text { have dropped out of the vaccination } \\
\text { schedule? }\end{array}$ & Specify. \\
\hline & Verify & $\begin{array}{l}\text { 8.1 Is there a permanent register } \\
\text { for child vaccination histories? }\end{array}$ & $\begin{array}{l}\text { Provided by the } \\
\text { government. }\end{array}$ \\
\hline & & $\begin{array}{cc}8.2 & \text { Are daily tallies/ registries } \\
\text { available? }\end{array}$ & \\
\hline$\sum$ & & $\begin{array}{cc}8.3 \quad \begin{array}{c}\text { Are aggregate reports } \\
\text { available? }\end{array} \\
\end{array}$ & \\
\hline Tृ & & $\begin{array}{l}\text { 8.4 Are the daily tallies/ registries } \\
\text { filled out correctly? }\end{array}$ & \\
\hline 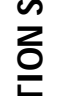 & & $\begin{array}{l}\text { 8.5 Are the aggregated vaccination } \\
\text { reports filled out correctly? }\end{array}$ & \\
\hline$\sum_{x}^{\infty}$ & Ask & $\begin{array}{l}\text { 8.6 Is the information recorded by } \\
\text { the client's residence? }\end{array}$ & $\begin{array}{l}\text { Consult the official } \\
\text { registries. }\end{array}$ \\
\hline 要 & & $\begin{array}{l}\text { 8.7 Is there a filing system for daily } \\
\text { tallies/ registries and aggregate } \\
\text { reports? }\end{array}$ & \\
\hline$>$ & & $\begin{array}{c}\text { 8.8 When a vaccine is } \\
\text { administered, is it recorded in all } \\
\text { the information system's } \\
\text { instruments (vaccination card, daily } \\
\text { tally/ registers, aggregate report, } \\
\text { etc.)? }\end{array}$ & \\
\hline
\end{tabular}




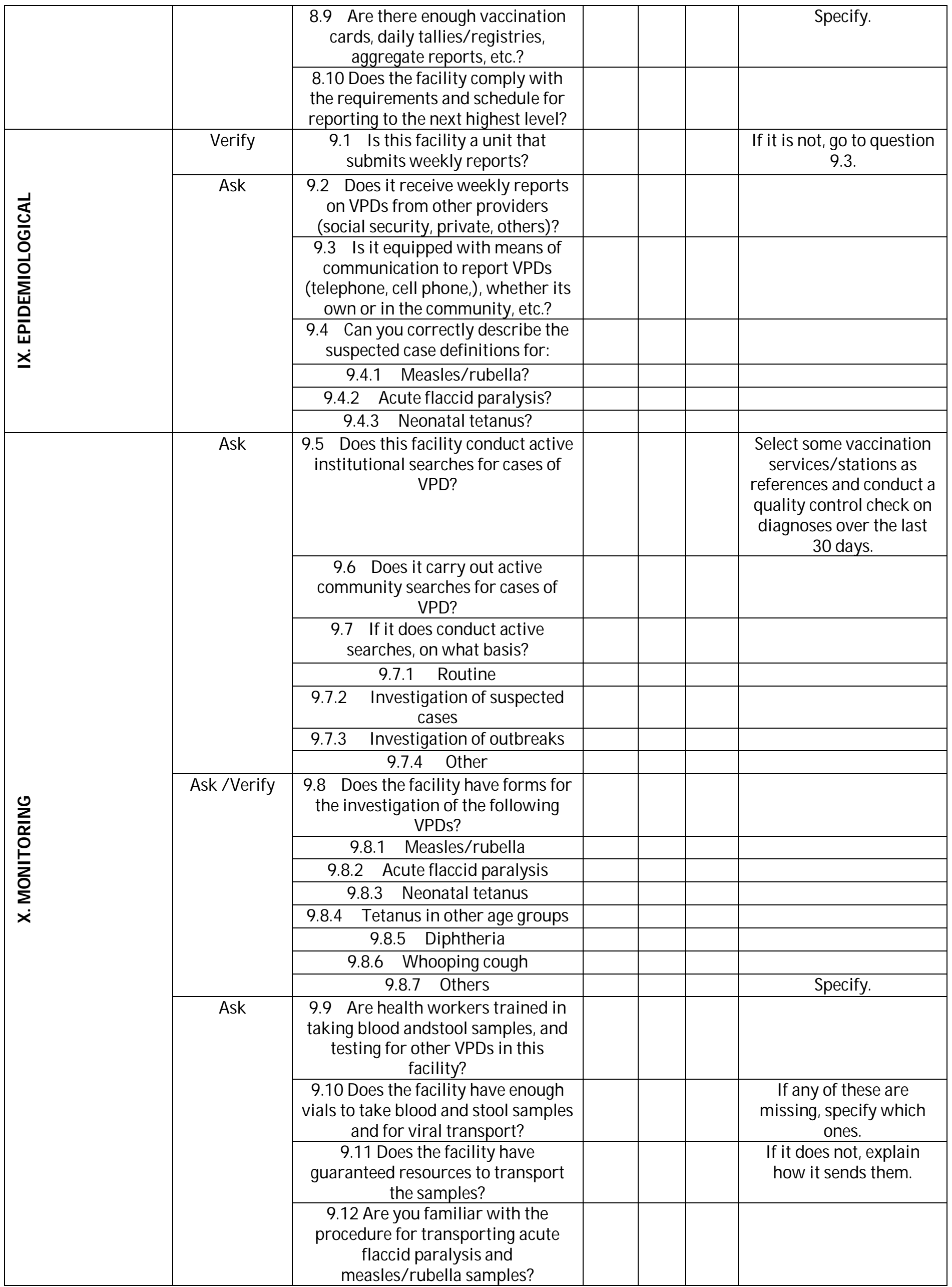




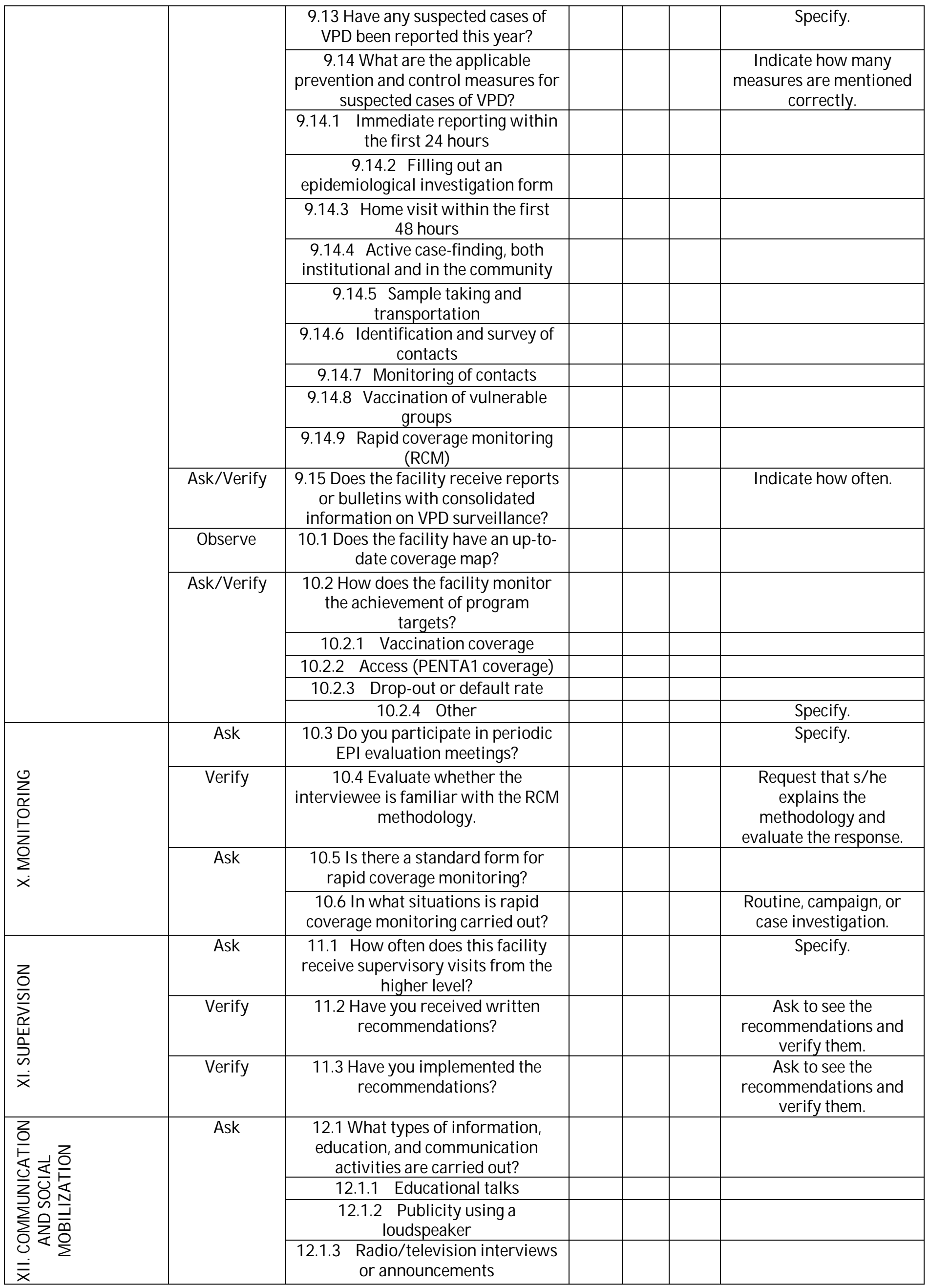




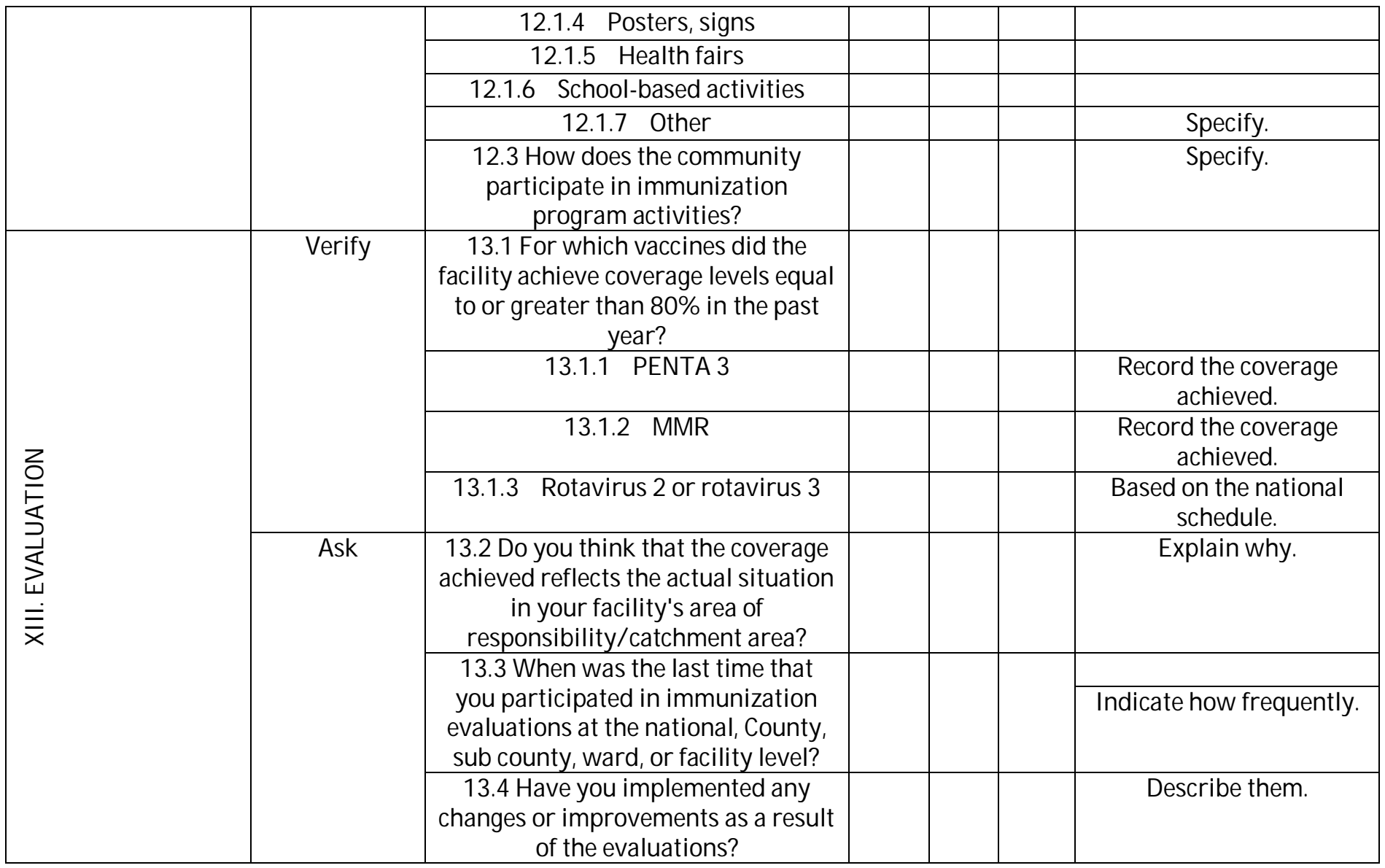

Table 27

\section{Conclusions and Recommendations}

Table 28

\begin{tabular}{|c|l|l|}
\hline Activity & Items & Total (Kshs) \\
\hline Proposal writing & $\begin{array}{l}\text { Library } \\
\text { Transport } \\
\text { Internet } \\
\text { Typesetting } \\
\text { Printing and binding } \\
\text { Stationery }\end{array}$ & \\
\hline Piloting of research instruments & Instrument copies and transport & 15000 \\
\hline Data collection & & 10000 \\
\hline Data analysis and report writing & & 100,000 \\
\hline Miscellaneous expenses & & 25000 \\
\hline Total & & 13000 \\
\hline
\end{tabular}

Table 29 


\begin{tabular}{|c|c|c|c|c|c|}
\hline & YEA & & & & \\
\hline Activity & July & August & September & October & November \\
\hline Topic selection & & & & & \\
\hline Proposal writing & & & & & \\
\hline $1^{\text {st }}$ Correction & & & & & \\
\hline Defense & & & & & \\
\hline Piloting & & & & & \\
\hline Data collection & & & & & \\
\hline Analysis & & & & & \\
\hline $\begin{array}{l}\text { Preparation of } \\
\text { Draft }\end{array}$ & & & & & \\
\hline $2^{\text {nd }}$ Correction & & & & & \\
\hline Final submission & & & & & \\
\hline
\end{tabular}

Table 30: Work Plan 